\title{
Trends in Home Purchase Lending: Consolidation and the Community Reinvestment Act
}

Robert B. Avery, Raphael W. Bostic, Paul S. Calem, and Glenn B. Canner, of the Board's Division of Research and Statistics, prepared this article. Kelly A. Bryant and John E. Matson provided research assistance.

Consolidation among banking institutions has substantially changed the structure of the banking industry. Between 1975 and 1997, the number of commercial banks and savings associations declined more than 40 percent. Most of this change was due to mergers and acquisitions, though in some years failures and liquidations were also important. Recent mergers and acquisitions have had particularly sizable effects on the shape of the industry, as many have involved the nation's largest and the most geographically diverse banking institutions.

Over the same broad period, the market for home mortgage lending has changed substantially. Notably, home mortgage lending is no longer primarily the province of banking institutions operating in the communities in which they have banking offices. ${ }^{1}$ In recent decades, mortgage and finance companies and banking organizations operating outside their local communities have gained a significant share of the mortgage market. ${ }^{2}$ Today, fewer than half of all home mortgage loans extended in any given community are originated by banking organizations with banking offices in that community.

These changes have fueled debate regarding their effects on the provision of home mortgage loans. One particular concern is that, as a consequence of these changes, lower-income and minority borrowers and borrowers in lower-income and minority neighborhoods may face reduced access to mortgage credit. In part, this concern reflects the belief that a shift away

1. In this article, the term banking institution refers to commercial banks and savings associations (savings banks and savings and loan associations). It does not include credit unions and mortgage or finance companies. The term banking office includes all locations qualifying as separate deposit-taking offices under federal guidelines.

2 . In this article, the term banking organization refers to commonly owned commercial banks and savings associations and their subsidiaries and affiliates, including, for example, mortgage and finance companies. Generally, a banking organization with multiple banking institutions is termed a bank or thrift holding company. from lending by institutions with local banking offices and acquisitions of small community-based banking institutions by large regional or national organizations may result in a transfer of decisionmaking authority from those familiar with the needs of local communities to those less knowledgeable about, and thus less responsive to, such needs. This article explores this issue by examining the relationship between consolidation among banking organizations in local markets and changes in home purchase lending over the 1993-97 period. We examine changes in total lending as well as changes in lending to lower-income and minority borrowers and neighborhoods. ${ }^{3}$

Previous research has considered the effects of consolidation on various aspects of banking, including small business lending, product pricing, and the geographic distribution of banking offices. ${ }^{4}$ These studies indicate that, in some cases, consolidation may significantly affect the provision of financial

3. Loans involving borrowers with income below 80 percent of the current-year median family income of their respective metropolitan statistical areas (MSAs) were classified as loans to lower-income borrowers. Loans to black, Asian, Hispanic, Native American, and "other race" borrowers were classified as loans to minorities. Information on the census tract location of the property being purchased was used to determine which loans were originated in lower-income or minority neighborhoods. Loans for properties in census tracts whose 1990 median family income was less than 80 percent of the 1990 median family income of their MSA were classified as loans to lower-income neighborhoods. Similarly, loans for properties in census tracts with more than 20 percent minority residents in 1990 were classified as loans to minority neighborhoods.

4. See, for example, Allen N. Berger, Anthony Saunders, Joseph M. Scalise, and Gregory F. Udell, "The Effects of Bank Mergers and Acquisitions on Small Business Lending," Journal of Financial Economics, vol. 50 (February 1999); Joseph Peek and Eric S. Rosengren, "Bank Consolidation and Small Business Lending: It's Not Just Size That Matters," Journal of Banking and Finance, vol. 22 (August 1998), pp. 799-820; Paul S. Calem and Leonard J. Nakamura, "Bank Branching and the Geography of Bank Pricing," Review of Economics and Statistics (forthcoming); Timothy H. Hannan and Robin A. Prager, "Do Substantial Horizontal Mergers Generate Significant Price Effects? Evidence from the Banking Industry," Journal of Industrial Economics, vol. 46 (December 1998), pp. 43252; Robert B. Avery, Raphael W. Bostic, Paul S. Calem, and Glenn B. Canner, "Changes in the Distribution of Banking Offices," Federal Reserve Bulletin, vol. 83 (September 1997), pp. 707-25; and Robert B. Avery, Raphael W. Bostic, Paul S. Calem, and Glenn B. Canner, "Consolidation and Bank Branching Patterns," Journal of Banking and Finance, vol. 23 (February 1999). 
services. This article extends the line of research by exploring the relationship between consolidation and lending to purchase homes.

This article also examines a related issue. Banking institutions have a legal responsibility to help serve the credit needs of their local communities-those areas in which they operate banking offices. The Community Reinvestment Act (CRA) of 1977 encourages banking institutions to help meet the credit needs of their local communities, including those of lower-income borrowers and of borrowers residing in lower-income neighborhoods. ${ }^{5}$ Because credit availability is believed to be essential to the economic health and vitality of neighborhoods, we also examine the relationship between consolidation and changes in home purchase lending by institutions in those areas where they have CRA responsibilities. Little previous research has been done on this narrower issue.

Until recently, only limited information has been available to systematically assess these issues. The analysis in this article relies on a new, specially constructed database that uses information on mergers, acquisitions, and failures of commercial banks and savings associations and data on the location of banking offices and neighborhood economic and demographic characteristics. These data are combined with data obtained pursuant to the Home Mortgage Disclosure Act (HMDA) for the years 1993 through 1997 on home purchase lending. ${ }^{6}$

\section{OVERVIEW OF THE RESULTS}

When measured at the market (county) level, the level of consolidation activity among banking organi-

5. The CRA directs the federal banking agencies to evaluate each institution's performance in meeting its community's credit needs and to consider this performance when acting on applications for mergers and acquisitions. For a discussion of the Community Reinvestment Act and the implementing regulation, see the Federal Reserve Press Release, April 24, 1995. Revisions to the implementing regulation in 1995 include performance tests that consider an institution's record of lending both to lower-income neighborhoods and to lower-income borrowers.

6. Although HMDA data on home purchase lending in metropolitan areas have been collected since 1977, 1993 is selected as the initial year for the analysis for two reasons. First, information on the income and race or ethnic origin of borrowers has been included in the HMDA data only since 1990, which precludes the analysis of the effects of mergers on borrowers arrayed by these characteristics before that year. Second, 1993 is the first year the HMDA data include the lending activity of most of the nation's most active independent mortgage companies-firms that extend about one-third of the home purchase loans in metropolitan areas. Analyses that exclude such active mortgage lenders would provide only a partial, and potentially distorted, picture of the mortgage market. zations appears to have had little relationship to changes in home purchase lending, both overall and to lower-income and minority borrowers and neighborhoods. This finding suggests that, in general, consolidation has not had significant anticompetitive effects on home purchase lending and that lending to lower-income and minority borrowers and neighborhoods has not been adversely affected by consolidation. This result holds despite the fact that consolidating organizations reduced their home purchase lending substantially in those areas in which they had banking offices. It appears that this reduction was more than offset by expanded home purchase lending by banking organizations in areas where they did not operate banking offices and by independent mortgage and finance companies and credit unions. In particular, consolidating banking organizations expanded their lending dramatically in areas where they did not operate banking offices. Thus, the very organizations that reduced their lending in markets where they operated offices were the organizations that expanded most in other areas. This result suggests that a driving force underlying changes in the home purchase lending market has been a desire by banking organizations to diversify their lending activity geographically.

Although banking institutions involved in consolidation reduced their overall lending in the communities where they had banking offices, this reduction did not disproportionately affect their lending to lower-income and minority borrowers and neighborhoods. The analysis shows that the typical consolidating organization generally increased the proportion of loans it extended to each of these groups within its local communities. These results are consistent with the view that the CRA has been effective in encouraging banking organizations, particularly those involved in consolidation, to serve lower-income and minority borrowers and neighborhoods.

A full understanding of these relationships requires a broader analysis and is beyond the scope of this article. For example, loan pricing, the complexity of product offerings, and the varied motivations driving consolidation must all be investigated fully to reach more definitive conclusions about the effects of consolidation on home purchase lending. It should also be emphasized that the results presented here reflect aggregate trends and may not apply to any particular market or consolidation.

\section{TRENDS IN BANKING CONSOLIDATION}

Over the past twenty years, the number of banking institutions declined substantially, from 18,679 in 
1975 to 11,077 in 1997—a decline of more than 40 percent. Just since 1993, the number of institutions has dropped about 18 percent. Consolidation during the 1980s and early 1990s was associated with a quickening pace of merger and acquisition activity along with substantial numbers of failures and liquidations. More recently, the decline in the number of banking institutions has been overwhelmingly the result of mergers and acquisitions. From 1993 through 1997, the number of banking institutions acquired in a merger or acquisition totaled 2,839 , or

\section{Geographic Restrictions in Banking}

Historically, the ability of banking institutions to merge or to buy one another and to establish branch offices both within and across local communities has been sharply curtailed by federal and state laws limiting geographic expansion by banks. ${ }^{1}$ Over the past two decades or so, many of these laws have been changed or eliminated, resulting in the easing of barriers to consolidation.

Before 1975 intrastate restrictions on bank branching were commonplace. For example, only seventeen states allowed commercial banks to establish offices within their state with few or no geographic restrictions. Since then, mainly in the 1980 s, geographic restrictions on intrastate branching have been removed or relaxed substantially in all states. The easing of these restrictions allows banking organizations to expand their geographic reach by establishing or acquiring branch offices rather than by merging with, or acquiring, another banking institution.

Geographic restrictions on banking extended beyond branching limitations to restrictions on banking institutions merging with, or acquiring, organizations in another state. For example, until the 1970 s, no state permitted out-of-state commercial banking organizations to operate in-state banking subsidiaries. State barriers began to fall in 1978 when Maine relaxed restrictions on entry by out-of-state holding companies. During the next fifteen years or so, every state except Hawaii followed suit by allowing some degree of interstate banking.

The Riegle-Neal Interstate Banking and Branching Efficiency Act of 1994 further eased restrictions on interstate banking in two important ways. First, it allowed bank holding companies to acquire a bank in any state provided certain conditions were met, including compliance with the CRA. Second, it substantially eased restrictions on interstate branching, although some important restrictions continue to exist.

1. For a discussion of the various banking laws, see Avery, Bostic, Calem, and Canner, "Changes in the Distribution of Banking Offices," pp. 712-13 and Anthony W. Cyrnak, "Bank Merger Policy and the New CRA Data," Federal Reserve Bulletin, vol. 84 (September 1998), pp. 703-15.
21 percent of all institutions. Over the same period, only 40 institutions were liquidated, and 431 new institutions were formed.

Consolidation in the banking industry has been driven in important ways by technological advances, globalization of financial services markets, and efforts to increase efficiency, reduce costs, or gain competitive advantage. Besides the effects of these economic factors, the pace of consolidation has accelerated because of the relaxation of regulatory restrictions on the ability of banking organizations to expand geographically and to establish banking offices, although some legal restrictions, including federal antitrust laws, continue to restrict potential combinations.7 (See box "Geographic Restrictions in Banking.")

Much of the industry's consolidation has involved mergers and acquisitions among banks that had been operating in different local markets within the same state, in different states within the same geographic region, or even in different regions. As a result, consolidation has been accompanied by a substantial broadening of the geographic reach of many banking organizations, so that many of the nation's largest organizations now operate across entire regions or even across multiple regions of the country. Whereas before 1980 only a handful of banking organizations operated in more than one state, by mid-1998, more than one-quarter of banking institution assets were owned by banking organizations with headquarters in another state. Moreover, a substantial increase has occurred in the share of total banking institution assets controlled by the largest banking organizations. ${ }^{8}$ In many cases, mergers have had a significant effect on concentration in local banking markets, although, on average across the United States, local market concentration has not increased substantially over time. One might expect this broad restructuring of the industry to have potential implications for retail banking relationships, such as the provision of financial services to lower-income and minority communities.

7. The two main federal antitrust laws are the Clayton Act of 1914 and the Sherman Act of 1890. In addition, the Bank Holding Company Act of 1956 and the Bank Merger Act of 1960 include antitrust provisions that specifically pertain to the activities of banking organizations.

8. The proportion of domestic banking assets accounted for by the 100 largest banking organizations rose from just over 50 percent in 1980 to 70 percent in June 1998 . Notably, however, small community banks have generally been able to retain their market shares and profitability in competition in banking markets increasingly dominated by the major banks (testimony by Governor Laurence H. Meyer before the Committee on Banking and Financial Services, U.S. House of Representatives, April 29, 1998). 


\section{INDUSTRY CONSOLIDATION AND LENDING TO LOWER-INCOME AND MINORITY BORROWERS AND NEIGHBORHOODS}

Access to home mortgage credit among lowerincome and minority borrowers and borrowers in lower-income and minority neighborhoods may be sensitive to changes caused by consolidation in the banking industry. This view derives from two general sets of arguments, which have potentially different implications. On the one hand, decentralized (local) decisionmaking may be especially important to a successful lower-income lending program, and consolidation may potentially reduce the role of local decisionmaking. On the other hand, because lending to lower-income and minority borrowers and neighborhoods sometimes involves special considerations of credit risk and often requires increased resources for risk-management activities, such lending may increase when consolidation improves the ability of institutions to efficiently evaluate, monitor, and manage credit risk.

These potential effects can vary, depending on a number of factors, such as whether the institutions to be combined operate within the same local communities. Other factors include competitive interactions among institutions, regulatory considerations, and the diminished role of savings associations. Ultimately, the effects of any given consolidation will depend on how it is implemented and on the commitment and ability of the management of the surviving institution to helping meet the credit needs of all segments of its community.

\section{The Role of Local Decisionmaking}

Successful home purchase lending to lower-income and minority borrowers and neighborhoods often requires considerable knowledge of the circumstances prevailing in local neighborhoods and expertise in evaluating the credit risks associated with such lending. ${ }^{9}$ Institutions active in such lending frequently use flexible credit standards, nontraditional measures of credit quality, a variety of credit enhancements (such as private and public subsidies and guarantees), and intensive monitoring of outstanding loans to expand their lending beyond those borrowers who are eligible for more conventional credit products. These institutions sometimes participate in local public agency programs in which the

9. See Board of Governors of the Federal Reserve System, Report to the Congress on Community Development Lending by Depository Institutions (Board of Governors, October 1993). public authority provides funds, in the form of either grants or low-cost loans, to help meet the borrower's downpayment or closing costs, or sets up a fund to guarantee repayment of the loan. These lenders also work with community organizations to identify and counsel prospective loan applicants and to monitor borrower repayment performance.

Some believe that mergers and acquisitions may have an adverse effect on lending to lower-income and minority borrowers and neighborhoods when they result in a transfer of decisionmaking to those outside the local community. In this view, centralized decisionmakers may find it more difficult to accurately assess nontraditional credit risks. They may have less knowledge about economic conditions or credit-risk factors specific to the local community, or they may have less flexibility in decisionmaking. Such concerns tend to be heightened when a large bank acquires a small bank, or when a bank is acquired by an institution that had not previously operated in the local market. ${ }^{10}$

A related concern is that mergers and acquisitions, as well as failures, may lead to branch closings and the loss of lending personnel who are familiar with the needs of the local community. Real estate agents, home builders, and those working for nonprofit groups or community organizations often develop working relationships with individual mortgage loan officers and may find the disruption of such relationships problematical.

\section{Opportunities Created by Technology Transfer, Information Sharing, and Risk Management}

Although mergers and acquisitions may lead to disruptions and changes in business relationships, some contend that consolidation often provides new opportunities to expand service to lower-income and minority borrowers and neighborhoods. Beneficial effects may arise through a variety of channels. For example, a small lender that becomes part of a larger organization may be able to take advantage of new technologies that reduce loan origination costs, such as automated underwriting, thus potentially improving access to credit for consumers. More generally, mergers and acquisitions may result in greater efficiencies in underwriting, application processing, and loan-servicing activities if scale economies can be achieved or if the firm being acquired has been

10. For discussion of the potential advantages of small banks, see Leonard I. Nakamura, "Small Borrowers and the Survival of the Small Bank," Federal Reserve Bank of Philadelphia, Business Review (November/December 1994), pp. 3-13. 
less well managed than the acquirer. The lifting of regulatory restrictions on geographic expansion may permit mergers that enhance the efficiency of the combined institutions, with the potential of making available additional resources for lending. Each of these efficiencies may increase an institution's ability to serve lower-income and minority borrowers and neighborhoods.

Consolidation may generate a sufficient volume of activity or allow the pooling of information to enable the development of certain types of expertise. For instance, so-called informational returns-to-scale may be present by which merging banks gain sufficient volume to become specialists in lending in lowerincome and minority communities, leading to greater efficiencies and reduced costs for such lending. ${ }^{11}$ Another type of informational advantage may come from a consolidation in which the parties are able to pool mutually beneficial information that would otherwise remain private. ${ }^{12}$

As noted, effective lending to lower-income borrowers often involves leveraging private- and publicsector funds. Public programs are frequently complex in their administration, and implementing such programs can require expenditures that smaller institutions have difficulty absorbing. ${ }^{13}$ As a consequence, new credit-related programs and other types of public-sector resources that broaden access to credit may become available to the customers of an acquired bank that previously lacked sufficient resources to fully participate in these programs.

Diversification of loan portfolios achieved through consolidation can potentially play an important role in fostering and sustaining a lending program targeted to lower-income borrowers or communities. Diversifying a portfolio by including loans from different geographic areas and different customer bases, both within and across communities, can enable a lender to achieve more predictable and stable earnings. Portfolio diversification may also enhance opportunities to package loans for resale in the secondary market, thereby providing new avenues to raise funds for additional lending. Moreover, consolidation may enhance mortgage lending opportunities if an institution facing capital constraints on additional lending merges with an institution that has a capital surplus.

11. See Robert B. Avery, Patricia E. Beeson, and Mark S. Sniderman, "Neighborhood Information and Mortgage Lending," Journal of Urban Economics (forthcoming).

12. See William W. Lang and Leonard I. Nakamura, "A Model of Redlining," Journal of Urban Economics, vol. 33 (1993), pp. 223-34.

13. See Report to the Congress on Community Development Lending by Depository Institutions.

\section{Market Performance Implications of Consolidation}

Consolidation may affect the competitive interaction among lending institutions in a market, with possible implications for market performance. A reduction in competition brought about by consolidation might adversely affect the availability of credit or creditrelated services in a community, although such effects might not disproportionately affect lower-income and minority borrowers and neighborhoods. One scenario in which lending to minority borrowers and minority neighborhoods might be adversely affected, at least in the short run, is a reduction in competitive pressures that enables some lenders to engage in discriminatory practices. ${ }^{14}$ More generally, if a reduction in competition in a given market results in higher prices or tighter credit standards, lower-income and minority borrowers may be disproportionately affected to the extent that a larger proportion of such borrowers are marginally qualified.

Consolidation may not only affect the behavior of the parties involved but may also have implications for other market participants. For instance, if the parties to a merger curtail their lending to lowerincome and minority borrowers and neighborhoods, then other banks in the market or new entrants may view this as an opportunity to gain customers. This expansion or entry by other institutions may offset some or all of the reduction in lending by the merged institution. ${ }^{15}$ Such offsets are also possible for failed institutions: Many failed banks and savings associations are acquired by healthy organizations or are reopened by investors entering the banking business.

\section{The Role of Regulation}

One aspect of government regulation of banking activity emphasizes encouraging the availability of

14. The theory of prejudicial discrimination developed by Becker suggests that lenders who enjoy market power may choose to sacrifice profits to engage in discriminatory practices. However, the theory also suggests that under competitive conditions, prejudicial discrimination cannot be sustained in the long run because capital will flow to those firms that forgo discrimination and consequently earn higher profits. See Gary S. Becker, The Economics of Discrimination (Chicago: University of Chicago Press, 1957).

15. Previous research finds evidence of offsetting responses by other market participants. For example, the closure of branches by merging institutions with overlapping branch networks is partly offset by the opening of new branches by other institutions. See Avery, Bostic, Calem, and Canner, "Changes in the Distribution of Banking Offices." Also, research on the effect of consolidation on small business lending finds that non-merging banks collectively tend to increase their supply of small business credit when mergers occur in their markets. See Berger, Saunders, Scalise, and Udell, "The Effects of Bank Mergers and Acquisitions on Small Business Lending." 
credit to lower-income and minority borrowers and neighborhoods. This policy is implemented in two ways. First, regulators periodically review the record of banking institutions in meeting their CRA and fair lending obligations. Second, CRA performance is also considered as part of the review of applications for mergers and acquisitions involving banking institutions.

All banking institutions are likely to be concerned about their periodic CRA evaluations. Institutions actively engaged in consolidation activity may be particularly concerned because of the role such evaluations play in the merger and acquisition approval process. In considering applications for mergers and acquisitions, regulators review the results of CRA compliance examinations, material submitted by the applicant, and comments from the public on the institution's performance. Poor CRA performance records may result in the denial of an application or delay of approval until the institution can demonstrate a record of satisfactory performance. ${ }^{16}$ It should be noted that home mortgage lending is only one of many activities that are considered when evaluating CRA performance. It is possible for an institution to earn a good CRA rating and make no mortgage loans.

Institutions with poor CRA track records are more likely to encounter broad-based substantive objections from the public when applying for approval of mergers or acquisitions, although even merging institutions with strong records of CRA performance sometimes encounter CRA-related protests. Such protests can result in adverse publicity and additional costs because the institution must often prepare extensive material to respond to them. To avoid CRA-related protests, as well as for other reasons, many banking institutions, particularly those likely to be involved in consolidation, have sought to enhance their records of serving their local communities by entering into agreements with community organizations. These agreements often include commitments by the institution to achieve targeted lending volumes in lower-income communities. ${ }^{17}$

Thus, for institutions active in mergers and acquisitions, the CRA provides incentives to maintain an aggressive program of lending to lower-income bor-

16. See Griffith L. Garwood and Dolores S. Smith, "The Community Reinvestment Act: Evolution and Current Issues," Federal Reserve Bulletin, vol. 79 (April 1993), pp. 251-67; and remarks by Governor Edward M. Gramlich, "Examining Community Reinvestment," at Widener University, Chester, Pennsylvania, November 6, 1998.

17. See Alex Schwartz, "Bank Lending to Minority and LowIncome Households and Neighborhoods: Do Community Reinvestment Agreements Make a Difference?" Journal of Urban Affairs, vol. 20, no. 3 (1998), pp. 269-301. rowers and neighborhoods. The incentives created by the CRA may contribute to a positive association between consolidation activity and lending to lowerincome borrowers or to lower-income neighborhoods.

By statute, regulators must also consider the competitive implications of proposed mergers and acquisitions along with their potential effects on the "convenience and needs" of the communities involved. Proposed consolidations that may have a substantial adverse effect on competition in a market generally are not approved unless there are countervailing convenience and needs considerations (such as the acquisition of a failing bank by a healthy institution). Often, proposed mergers or acquisitions that initially raise serious anticompetitive issues are approved only after the parties agree to sell (divest) banking offices with deposits and assets to limit their increase in market share. Thus, regulatory review of proposed mergers and acquisitions mitigates the possibility that consolidation may adversely affect competition and credit availability in the local community.

\section{Consolidations Involving Savings Associations}

Many of the recent consolidations in banking have involved the acquisition of savings associations by commercial banks, a development that may affect home purchase lending. Savings associations are encouraged, through tax provisions and other incentives, to hold the majority of their assets in home mortgages and also face restrictions on the amount of commercial lending they are permitted. Because commercial banks do not have similar incentives to extend mortgages and are not similarly restricted in their non-mortgage lending, the share of total assets devoted to mortgages may decline in the wake of commercial bank acquisitions of savings associations.

\section{CONSOLIDATION AND MARKET-LEVEL CHANGES IN MORTGAGE LENDING}

Given the variety of possible theoretical effects of consolidation on lending to lower-income and minority borrowers and neighborhoods, empirical analysis can help provide a greater understanding of this issue. We use a specially constructed database that combines information on mergers, acquisitions, and failures of banking institutions with data on the location of banking offices, neighborhood economic and demographic characteristics, and home purchase lending activity in metropolitan areas. (See the appendix for more details on the construction of the database.) The analysis of these data provides information on trends in lending patterns in geographic areas 
with varying levels of consolidation activity. This information allows us to assess the degree to which consolidation is associated with changes in home purchase lending overall, as well as to lower-income and minority borrowers and neighborhoods.

\section{Analytic Framework}

The unit of analysis for this research is the county. The county represents a compromise between the MSA and smaller geographic units, such as a ZIP code or census tract. On the one hand, for some small banking organizations, the CRA service area may be smaller than a county. In addition, for some consolidations a focus of concern may be the effects on an area smaller than a county. On the other hand, for large organizations CRA evaluations may be based on their lending throughout an entire MSA. It should be noted that more than half of the MSAs in the United States are made up of only one county, and thus for these MSAs, the distinction between the county and the MSA makes no difference.

In a given county, we count the number of home purchase loans extended overall and those extended to lower-income and minority borrowers and neighborhoods by all lenders. We compare counties that had high levels of consolidation activity with those that had little or no consolidation activity. Data limitations force us to restrict the analysis to lending in counties in metropolitan areas (see the appendix).

The analysis focuses on trends in home purchase lending during two periods, 1993-95 and 1995-97. We use three-year study periods because it may take some time for the effects of a consolidation to influence home purchase lending. For example, the integration of mortgage lending operations, including the retraining of staff and coordination of mortgage underwriting activities, may require considerable effort and time. Too long a study period, however, makes it difficult to separate the effects of consolidation from other factors that may influence home purchase lending. Three-year study periods seem a reasonable compromise between these two concerns. Further, two periods are used because significant variation occurred in the overall patterns of home purchase lending between 1993-95 and 1995-97. Comparing and contrasting the observed relationships in the two periods allow us to draw more definitive conclusions about how consolidation influences home purchase lending patterns.

Consolidations are defined at the level of the banking organization. Both institutional mergers and holding company acquisitions are treated as consolidations. Mergers among subsidiaries of the same holding company, however, are not considered consolidations. All structural changes involving a banking organization over each three-year period are treated as a single consolidation. Thus, a consolidation might involve multiple mergers and acquisitions (see the appendix). To count as a consolidation in a given county, the consolidation must have involved the acquisition of a banking institution operating banking offices in that county. Counties in which only the acquiring institution operated banking offices are not considered to have had consolidations.

Counties are categorized by their level of consolidation activity. To determine this level, we calculate the proportion of all home purchase loans in a county in the first year of each study period that was originated by banking organizations with a consolidation in the county. Counties are grouped by this proportion into three categories: (1) counties in which no organizations were involved in a consolidation; (2) counties in which the proportion of loans extended by organizations involved in consolidation was less than or equal to the median share of loans extended by organizations involved in consolidation for that period (counties with low consolidation activity); and (3) counties in which the proportion of loans extended by organizations involved in consolidation was greater than the median share of loans extended by organizations involved in consolidation for that period (counties with high consolidation activity). For the latter two groups, the median share is calculated using only those counties that had consolidations.

Counties are further divided along a number of other dimensions. To differentiate the effects of consolidation in markets of different sizes and growth rates, counties are grouped by the number of residents in the county as of 1995 and by the change in their populations over the 1993-95 period. In addition, because market structure may influence lending strategies, counties are grouped according to the market concentration in the MSA in which the county is located, which was measured by a HerfindahlHirschman index (HHI) based on banking deposits in the MSA. ${ }^{18}$ A threshold HHI value of 1800 is used

18. A Herfindahl-Hirschman index (HHI) based on banking deposits is a standard measure used to assess the competitiveness of banking markets. The Federal Reserve Board includes thrift deposits at 50 percent in calculating market HHI values for its bank merger analysis. (For more details, see Anthony W. Cyrnak, "Bank Merger Policy and the New CRA Data," Federal Reserve Bulletin, vol. 84 (September 1998), pp. 703-15.) In this analysis, we include deposits by savings associations at 100 percent in calculating HHI values for each MSA because savings associations are active competitors in the home mortgage lending market. 
because regulators consider a post-consolidation HHI value of more than 1800 as one signal that the consolidation may have anticompetitive effects in the market.

\section{General Patterns of Home Purchase Lending}

Over the 1993-97 period, home purchase lending in metropolitan areas expanded robustly, as a strong economy and job market and relatively low interest rates encouraged additional home buying (table 1). Although lower-income and minority borrowers and neighborhoods accounted for a moderate proportion of home purchase loans each year, the amount of lending to such groups increased at a faster rate than that to other groups. ${ }^{19}$ For example, over 1993-97, lending to lower-income borrowers increased about 31 percent (measured by the change in the number of loans), while lending to higher-income borrowers

19. For additional information about these patterns, see the Federal Financial Institutions Examination Council press release, August 6, 1998. (those with incomes greater than 120 percent of the median family income of the MSA where they purchased a home) rose 18 percent (table 2, memo item). Similarly, lending to minority borrowers increased about 53 percent, while lending to nonminority borrowers increased 13 percent.

The substantial growth in lending to lower-income and minority borrowers and neighborhoods in recent years is the consequence of many factors. Besides the bolstering of demand by the strong economy and job market, relatively low interest rates on home loans and relatively modest changes in home prices have combined to improve the affordability of homebuying. Moreover, since the early 1990s, originators of conventional home purchase loans have initiated a wide variety of affordable home purchase lending programs intended to benefit lower-income and minority borrowers and neighborhoods. ${ }^{20}$ Significant

20. For more information see Robert B. Avery, Raphael W. Bostic, Paul S. Calem, and Glenn B. Canner, "Credit Risk, Credit Scoring, and the Performance of Home Mortgages," Federal Reserve Bulletin, vol. 82 (July 1996), pp. 621-48.

1. Distribution of home purchase loans, by characteristic of borrower and neighborhood, 1993-97

\begin{tabular}{|c|c|c|c|c|c|c|c|c|c|c|}
\hline \multirow{2}{*}{$\begin{array}{l}\text { Borrower or census } \\
\text { tract characteristic }\end{array}$} & \multicolumn{2}{|c|}{1993} & \multicolumn{2}{|c|}{1994} & \multicolumn{2}{|c|}{1995} & \multicolumn{2}{|c|}{1996} & \multicolumn{2}{|c|}{1997} \\
\hline & Number & Percent & Number & Percent & Number & Percent & Number & Percent & Number & Percent \\
\hline \multicolumn{11}{|l|}{$\begin{array}{l}\text { BORROWER } \\
\text { Racial or ethnic group } 1\end{array}$} \\
\hline Minority ................. & 380,002 & 16.1 & 483,781 & 19.0 & 495,815 & 20.3 & 556,229 & 20.0 & 582,816 & 20.7 \\
\hline Nonminority ........ & $1,974,386$ & 83.9 & $2,065,434$ & 81.0 & $1,950,183$ & 79.7 & $2,231,494$ & 80.0 & $2,234,608$ & 79.3 \\
\hline Total .... & $2,354,388$ & 100.0 & $2,549,215$ & 100.0 & $2,445,998$ & 100.0 & $2,787,723$ & 100.0 & $2,817,424$ & 100.0 \\
\hline \multicolumn{11}{|l|}{ 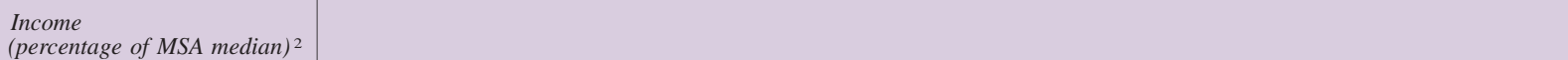 } \\
\hline Less than $50 \ldots \ldots \ldots \ldots \ldots$ & 156,639 & 6.6 & 190,523 & 7.4 & 159,126 & 6.4 & 200,401 & 7.1 & 213,763 & 7.4 \\
\hline $50-79 \ldots \ldots$ & 488,486 & 20.5 & 532,891 & 20.6 & 516,317 & 20.8 & 608,596 & 21.5 & 629,636 & 21.8 \\
\hline $80-119$ & 722,877 & 30.3 & 773,162 & 30.0 & 744,231 & 30.0 & 838,997 & 29.7 & 836,960 & 29.0 \\
\hline 120 or more & $1,020,915$ & 42.7 & $1,084,337$ & 42.0 & $1,058,458$ & 42.7 & $1,178,732$ & 41.7 & $1,205,063$ & 41.8 \\
\hline Total $\ldots . .$. & $2,388,917$ & 100.0 & $2,580,913$ & 100.0 & $2,478,132$ & 100.0 & $2,826,726$ & 100.0 & $2,885,422$ & 100.0 \\
\hline \multicolumn{11}{|l|}{$\begin{array}{l}\text { Racial or ethnic composition } \\
\text { (minorities as a percentage } \\
\text { of population })^{3}\end{array}$} \\
\hline Less than $5 \ldots \ldots \ldots \ldots$ & 772,595 & 31.8 & 801,662 & 30.8 & 775,968 & 30.9 & 885,891 & 30.8 & 877,244 & 29.8 \\
\hline $5-9 \ldots \ldots$ & 530,333 & 21.9 & 556,054 & 21.3 & 528,118 & 21.0 & 609,897 & 21.2 & 625,635 & 21.2 \\
\hline $10-19$ & 526,196 & 21.7 & 572,154 & 21.9 & 547,444 & 21.8 & 635,674 & 22.1 & 661,654 & 22.4 \\
\hline $20-49$ & 414,706 & 17.1 & 463,051 & 17.8 & 447,381 & 17.8 & 515,328 & 17.9 & 536,525 & 18.2 \\
\hline 50 or more & 183,119 & 7.5 & 213,886 & 8.2 & 214,635 & 8.5 & 233,508 & 8.1 & 247,469 & 8.4 \\
\hline Total $\ldots \ldots \ldots \ldots \ldots \ldots$ & $2,426,949$ & 100.0 & $2,606,807$ & 100.0 & $2,513,546$ & 100.0 & $2,880,298$ & 100.0 & $2,948,527$ & 100.0 \\
\hline \multicolumn{11}{|l|}{$\begin{array}{l}\text { Income (median family) } \\
\text { (percentage of MSA median) }{ }^{3}\end{array}$} \\
\hline Less than $50 \ldots \ldots \ldots \ldots \ldots$ & 26,689 & 1.1 & 30,592 & 1.1 & 32,179 & 1.3 & 35,777 & 1.2 & 38,034 & 1.3 \\
\hline $50-79$ & 227,706 & 9.4 & 255,575 & 9.8 & 266,002 & 10.6 & 294,069 & 10.2 & 301,398 & 10.2 \\
\hline $80-119$ & $1,202,522$ & 49.5 & $1,301,267$ & 49.9 & $1,279,304$ & 50.9 & $1,455,975$ & 50.5 & $1,476,450$ & 50.1 \\
\hline 120 or more & 970,032 & 40.0 & $1,019,373$ & 39.1 & 936,061 & 37.2 & $1,094,477$ & 40.0 & $1,132,645$ & 38.4 \\
\hline Total $\ldots .$. & $2,426,949$ & 100.0 & $2,606,807$ & 100.0 & $2,513,546$ & 100.0 & $2,880,298$ & 100.0 & $2,948,527$ & 100.0 \\
\hline All & $2,430,844$ & & $2,609,469$ & & $2,515,906$ & & $2,882,921$ & & $2,951,583$ & \\
\hline
\end{tabular}

NoTE. Includes only owner-occupied one- to four-family home purchase loans extended for properties in metropolitan statistical areas (MSAs). The counties included are those that were in MSAs throughout the period. Thus, loan counts will differ from figures published by the Federal Financial Institutions Examination Council (FFIEC). Totals for the four borrower and neighborhood categories differ because information regarding borrower race or ethnic status and income or property location was not reported for all loans.
1. Loans to black, Asian, Hispanic, Native American and "other race" borrowers are classified as minority loans.

2. MSA median family income is estimated for each year by the Department of Housing and Urban Development.

3. Median family income and racial composition are derived from the 1990 Census of Population and Housing. 
2. Change in home purchase lending, by characteristic of borrower and neighborhood, 1993-97

Percent

\begin{tabular}{|c|c|c|c|c|c|}
\hline $\begin{array}{l}\text { Borrower or census } \\
\text { tract characteristic }\end{array}$ & $\begin{array}{c}1993 \\
\text { to } \\
1994\end{array}$ & $\begin{array}{c}1994 \\
\text { to } \\
1995\end{array}$ & $\begin{array}{l}1995 \\
\text { to } \\
1996\end{array}$ & $\begin{array}{c}1996 \\
\text { to } \\
1997\end{array}$ & $\begin{array}{l}\text { Memo } \\
1993-97\end{array}$ \\
\hline $\begin{array}{l}\text { BORROWER } \\
\text { Racial or ethnic } \\
\text { group }^{1}\end{array}$ & & & & & \\
\hline Minority ... & 27.3 & 2.5 & 12.2 & 4.8 & 53.4 \\
\hline $\begin{array}{c}\text { Nonminority } \\
\text { Total }\end{array}$ & $\begin{array}{l}4.6 \\
8.3\end{array}$ & -5.6 & 14.4 & .1 & $\begin{array}{l}13.2 \\
107\end{array}$ \\
\hline Total ...... & 8.3 & -4.0 & 14.0 & 1.1 & 19.7 \\
\hline $\begin{array}{l}\text { Income } \\
\text { (percentage of MSA } \\
\text { median) })^{2}\end{array}$ & & & & & \\
\hline Less than 50 & 21.6 & -16.5 & 25.9 & 6.7 & 36.5 \\
\hline $50-79 \quad \ldots \ldots$ & 9.1 & -3.1 & 17.9 & 3.5 & 28.9 \\
\hline $80-119$ & 7.0 & -3.7 & 12.7 & -.2 & 15.8 \\
\hline 120 or more & 6.2 & -2.4 & 11.4 & 2.2 & 18.0 \\
\hline Total ....... & 8.0 & -4.0 & 14.1 & 2.1 & 20.8 \\
\hline $\begin{array}{l}\text { NEIGHBORHOOD } \\
\text { (CENSUS TRACT) }\end{array}$ & & & & & \\
\hline $\begin{array}{l}\text { Racial or ethnic } \\
\text { composition } \\
\text { (minorities as a } \\
\text { percentage of } \\
\text { population) }\end{array}$ & & & & & \\
\hline Less than 5 & 3.8 & -3.2 & 14.2 & -1.0 & 13.5 \\
\hline & 4.8 & -5.0 & 15.5 & 2.6 & 18.0 \\
\hline $10-19$ & 8.7 & -4.3 & 16.1 & 4.1 & 25.7 \\
\hline $20-49$ & 11.7 & -3.4 & 15.2 & 4.1 & 29.4 \\
\hline 50 or more & 16.8 & 4 & 8.8 & 6.0 & 35.1 \\
\hline Total & 7.4 & -3.6 & 14.6 & 2.4 & 21.5 \\
\hline $\begin{array}{l}\text { Income (median family } \\
\text { (percentage of MSA } \\
\text { median) }{ }^{3}\end{array}$ & & & & & \\
\hline Less than 50 & 14.6 & 5.2 & 11.2 & 6.3 & 42.5 \\
\hline $50-79 \ldots \ldots$ & 12.2 & 4.1 & 10.6 & 2.5 & 32.4 \\
\hline $80-119$. & 8.2 & -1.7 & 13.8 & 1.4 & 22.8 \\
\hline 120 or more & 5.1 & -8.2 & 16.9 & 3.5 & 16.8 \\
\hline Total .... & 7.4 & -3.6 & 14.6 & 2.4 & 21.5 \\
\hline All & 7.3 & -3.6 & 14.6 & 2.4 & 21.4 \\
\hline
\end{tabular}

NoTE. Includes only owner-occupied one- to four-family home purchase loans extended for properties in MSAs. The counties included are those that were in MSAs throughout the period. Thus, loan counts will differ from figures published by the FFIEC. Totals for the four borrower and neighborhood categories differ because information regarding borrower race or ethnic status and income or property location was not reported for all loans.

1. Loans to black, Asian, Hispanic, Native American and "other race" borrowers are classified as minority loans.

2. MSA median family income is estimated for each year by the Department of Housing and Urban Development.

3. Median family income and racial composition are derived from the 1990 Census of Population and Housing.

changes in government-backed lending programs in recent years have also improved opportunities for lower-income borrowers. For example, the Federal Housing Administration (FHA) has reduced the up-front mortgage insurance premium for FHAinsured loans, raised the maximum loan amount eligible for FHA backing, and increased underwriting flexibility.

\section{The Effects of Consolidation}

To analyze the effects of consolidation activity on home purchase lending patterns, we track changes in the number of home purchase loans originated in counties sorted by their degree of consolidation activity for each of the two study periods. In each period nearly all home purchase loans were extended in counties that had some consolidation activity (table 3). Only about 5 percent of loans were originated in MSA counties with no consolidation activity during the two study periods. Loan volumes were similar in counties with low levels of consolidation activity and in those with high levels. Because nearly all home purchase loans in MSAs were originated in counties with some level of consolidation, the most useful comparison is between counties with relatively low levels of consolidation activity and those with relatively high levels. The noteworthy relationships between consolidation and changes in lending are those that are consistent across time periods and robust when controls for other factors are considered. We use multivariate regressions to help identify such relationships, although these regressions are not shown in this article.

Percentage changes in the number of home purchase loans extended in a county are not significantly different in areas with high and those with low consolidation activity for both overall lending and across the four borrower and neighborhood lending categories (table 3 ). There are only minor exceptions to this result. In particular, for the 1993-95 period smaller counties with high levels of consolidation have a lower growth rate of home purchase loans-both overall and for lower-income applicants-than smaller counties with low levels of consolidation activity.

Although growth rates do not generally differ by the level of consolidation activity in a county, they do differ between periods and across the lending categories. For example, the growth in the number of loans to minority borrowers is generally greater than the growth in the number of loans to lowerincome borrowers. However, within any given borrower or neighborhood category, there is little difference in the loan growth rate between counties with low consolidation activity and those with high consolidation activity. This result also holds when counties are grouped by population, population growth rate, and market concentration.

The failure to find a consistent and robust relationship between the level of banking consolidation and changes in home purchase lending has two possible explanations. Consolidating organizations may not change their home purchase lending behavior. Alternatively, any changes in home purchase lending activity by consolidating organizations may be offset by other market participants. Home purchase lending 
3. Home purchase loans, by level of consolidation activity in a county, county characteristic, and market concentration level, 1993-95 and 1995-97

\begin{tabular}{|c|c|c|c|c|c|c|c|c|c|c|c|c|}
\hline \multirow{4}{*}{$\begin{array}{c}\text { Level of } \\
\text { consolidation } \\
\text { activity } \\
\text { by county } \\
\text { characteristic } \\
\text { and market } \\
\text { concentration } \\
\text { level }\end{array}$} & \multirow{2}{*}{\multicolumn{4}{|c|}{ All borrowers }} & \multicolumn{8}{|c|}{ Type of borrower ${ }^{1}$} \\
\hline & & & & & & Minc & rity & & & Lower- & ncome & \\
\hline & \multicolumn{2}{|c|}{ 1993-95 } & \multicolumn{2}{|c|}{ 1995-97 } & \multicolumn{2}{|c|}{ 1993-95 } & \multicolumn{2}{|c|}{ 1995-97 } & \multicolumn{2}{|c|}{ 1993-95 } & \multicolumn{2}{|c|}{ 1995-97 } \\
\hline & $\begin{array}{l}\text { Initial } \\
\text { number }\end{array}$ & $\begin{array}{c}\text { Percentage } \\
\text { change }\end{array}$ & $\begin{array}{l}\text { Initial } \\
\text { number }\end{array}$ & $\begin{array}{c}\text { Percentage } \\
\text { change }\end{array}$ & $\begin{array}{c}\text { Initial } \\
\text { number }\end{array}$ & $\begin{array}{c}\text { Percentage } \\
\text { change }\end{array}$ & $\begin{array}{l}\text { Initial } \\
\text { number }\end{array}$ & $\begin{array}{c}\text { Percentage } \\
\text { change }\end{array}$ & $\begin{array}{c}\text { Initial } \\
\text { number }\end{array}$ & $\begin{array}{l}\text { Percentage } \\
\text { change }\end{array}$ & $\begin{array}{l}\text { Initial } \\
\text { number }\end{array}$ & $\begin{array}{c}\text { Percentage } \\
\text { change }\end{array}$ \\
\hline \multicolumn{13}{|l|}{$\begin{array}{c}\text { LEVEL OF } \\
\text { CONSOLIDATION } \\
\text { ACTIVITY }^{2}\end{array}$} \\
\hline Overall ... & $2,430,844$ & 3 & $2,515,906$ & 17 & 380,002 & 30 & 495,815 & 18 & 645,125 & 5 & 675,443 & 25 \\
\hline None & 116,023 & 15 & 155,886 & 10 & 9,744 & 44 & 15,203 & 3 & 33,425 & 16 & 44,909 & 21 \\
\hline Low & $1,120,439$ & 4 & $1,030,464$ & 17 & 193,798 & 27 & 172,853 & 18 & 285,155 & 5 & 285,285 & 25 \\
\hline High & $1,194,382$ & 2 & $1,329,465$ & 19 & 176,460 & 33 & 307,759 & 18 & 326,545 & 3 & 345,249 & 25 \\
\hline \multicolumn{13}{|l|}{ By county size 3} \\
\hline 500,000 or less & $1,204,576$ & 3 & $1,243,745$ & 14 & 111,916 & 35 & 150,557 & 16 & 334,858 & 3 & 343,915 & 23 \\
\hline None ........ & 108,945 & 14 & 145,480 & 11 & 8,854 & 43 & 10,088 & 12 & 31,381 & 16 & 42,446 & 21 \\
\hline Low ... & 526,331 & 5 & 587,619 & 15 & 55,682 & 33 & 74,501 & 17 & 140,076 & 3 & 162,441 & 25 \\
\hline High & 569,300 & 0 & 510,646 & 13 & 47,380 & 34 & 65,968 & 15 & 163,401 & 0 & 139,028 & 22 \\
\hline \multicolumn{13}{|l|}{ More than } \\
\hline 500,000 & $1,226,268$ & 4 & $1,272,161$ & 21 & 268,086 & 29 & 345,258 & 18 & 310,267 & 7 & 331,528 & 27 \\
\hline None & 7,078 & 16 & 10,506 & 0 & 890 & 57 & 5,115 & -16 & 2,044 & 19 & 2,463 & 22 \\
\hline Low. & 594,108 & 3 & 442,845 & 19 & 138,116 & 25 & 98,352 & 18 & 145,079 & 7 & 122,844 & 26 \\
\hline High ... & 625,082 & 5 & 818,810 & 22 & 129,080 & 33 & 241,791 & 19 & 163,144 & 7 & 206,221 & 27 \\
\hline \multicolumn{13}{|l|}{$\begin{array}{l}\text { By county } \\
\text { growth rate } 4\end{array}$} \\
\hline Low growth. & $1,287,804$ & 2 & $1,314,868$ & 16 & 226,156 & 26 & 285,737 & 14 & 350,217 & 5 & 366,449 & 21 \\
\hline None ..... & 55,055 & 10 & 89,039 & 7 & 5,377 & 39 & 11,474 & -3 & 15,605 & 13 & 25,857 & 18 \\
\hline Low .... & 529,018 & 2 & 402,281 & 15 & 107,442 & 22 & 74,072 & 13 & 135,730 & 5 & 121,810 & 21 \\
\hline High & 703,731 & 2 & 823,548 & 17 & 113,337 & 29 & 200,191 & 15 & 198,882 & 4 & 218,782 & 22 \\
\hline High growth & $1,143,040$ & 5 & $1,201,038$ & 19 & 153,846 & 37 & 210,078 & 22 & 294,908 & 5 & 308,994 & 29 \\
\hline None ..... & 6,098 & 19 & 66,947 & 15 & 4,307 & 51 & 3,729 & 19 & 17,820 & 19 & 19,052 & 25 \\
\hline Low ... & 591,421 & 5 & 628,183 & 18 & 86,356 & 33 & 98,781 & 21 & 149,425 & 5 & 163,475 & 29 \\
\hline High $\ldots$ & 490,651 & 3 & 505,908 & 21 & 63,123 & 40 & 107,568 & 24 & 127,663 & 2 & 126,467 & 31 \\
\hline \multicolumn{13}{|l|}{$\begin{array}{l}\text { By market } \\
\text { concentration } 5\end{array}$} \\
\hline Less than 1800 & $2,122,710$ & 4 & $2,166,613$ & 18 & 344,785 & 30 & 445,233 & 18 & 552,825 & 5 & 579,286 & 25 \\
\hline None ......... & 93,065 & 16 & 109,407 & 12 & 7,851 & 46 & 7,631 & 11 & 27,276 & 17 & 32,584 & 23 \\
\hline Low & $1,028,222$ & 3 & 845,191 & 17 & 179,838 & 28 & 143,724 & 17 & 260,159 & 5 & 234,545 & 25 \\
\hline High & $1,001,423$ & 3 & $1,212,015$ & 20 & 157,096 & 32 & 293,878 & 19 & 265,390 & 5 & 312,157 & 26 \\
\hline 1800 and more & 308,134 & 2 & 349,293 & 12 & 35,217 & 31 & 50,582 & 13 & 92,300 & 1 & 96,157 & 23 \\
\hline None...... & 22,958 & 8 & 46,579 & 7 & 1,893 & 36 & 7,572 & -6 & 6,149 & 12 & 12,325 & 17 \\
\hline Low ... & 92,217 & 5 & 185,273 & 16 & 13,960 & 16 & 29,129 & 20 & 24,996 & 5 & 50,740 & 27 \\
\hline High .. & 192,959 & 1 & 117,441 & 8 & 19,364 & 42 & 13,881 & 8 & 61,155 & -2 & 33,092 & 19 \\
\hline
\end{tabular}

is an intensely competitive business. ${ }^{21}$ Entry by firms is relatively easy, a typical market has many lenders, and a mature secondary market allows institutions to readily sell loans they originate and to extend additional credit.

The analysis presented here does not provide a complete picture of the effect of consolidation on home purchase lending. For example, it does not identify changes in prices or product offerings. Further, it does not provide information about the behavior of any individual lender or lender type. However, the results strongly suggest that over the entire study period the level of consolidation activity among banking organizations in a county had little effect on the growth of total home purchase lending or on the

21. The competitive nature of the market becomes apparent when comparing HHI measures based on home purchase loans with HHI measures based on deposits. The former are consistently lower than the latter, and often by a substantial amount. growth of lending to any of the four borrower and neighborhood categories.

\section{CONSOLIDATION AND MORTGAGE LENDING AT THE BANKING ORGANIZATION LEVEL}

The results presented in the last section showed little relationship between consolidation activity and changes in home purchase lending in a county. The two potential explanations offered characterized changes in the behavior of consolidating organizations differently. In this section, we focus on these differences by examining changes in the behavior of consolidating banking organizations. Because the CRA mandates a special responsibility for banking organizations to serve the credit needs of residents of those areas where they operate banking offices, we distinguish between changes in their behavior in counties where they had banking offices before the 


\section{3.-Continued}

\begin{tabular}{|c|c|c|c|c|c|c|c|c|}
\hline \multirow{4}{*}{$\begin{array}{l}\text { Level of } \\
\text { consolidation } \\
\text { activity } \\
\text { by county } \\
\text { characteristic } \\
\text { and market } \\
\text { concentration } \\
\text { level }\end{array}$} & \multicolumn{8}{|c|}{ Type of neighborhood ${ }^{1}$} \\
\hline & \multicolumn{4}{|c|}{ Minority } & \multicolumn{4}{|c|}{ Lower-income } \\
\hline & \multicolumn{2}{|c|}{$1993-95$} & \multicolumn{2}{|c|}{$1995-97$} & \multicolumn{2}{|c|}{$1993-95$} & \multicolumn{2}{|c|}{$1995-97$} \\
\hline & $\begin{array}{c}\text { Initial } \\
\text { number }\end{array}$ & $\begin{array}{c}\text { Percentage } \\
\text { change }\end{array}$ & $\begin{array}{c}\text { Initial } \\
\text { number }\end{array}$ & $\begin{array}{l}\text { Percentage } \\
\text { change }\end{array}$ & $\begin{array}{c}\text { Initial } \\
\text { number }\end{array}$ & $\begin{array}{l}\text { Percentage } \\
\text { change }\end{array}$ & $\begin{array}{l}\text { Initial } \\
\text { number }\end{array}$ & $\begin{array}{l}\text { Percentage } \\
\text { change }\end{array}$ \\
\hline \multicolumn{9}{|l|}{$\begin{array}{l}\text { LEVEL OF } \\
\text { CONSOLIDATION } \\
\text { ACTIVITY }^{2}\end{array}$} \\
\hline Overall & 597,825 & 11 & 662,016 & 18 & 254,395 & 17 & 298,181 & 14 \\
\hline None & 19,014 & 23 & 22,629 & 5 & 11,635 & 30 & 18,017 & $\begin{array}{r}14 \\
7\end{array}$ \\
\hline Low . & 335,192 & 7 & 247,737 & 15 & 115,026 & 12 & 116,831 & 13 \\
\hline High & 243,619 & 15 & 391,650 & 21 & 127,734 & 21 & 163,333 & 15 \\
\hline \multicolumn{9}{|l|}{ By county size 3} \\
\hline 500,000 or less & 185,540 & 12 & 207,501 & 12 & 114,231 & 15 & 131,010 & 10 \\
\hline None ......... & 18,175 & 22 & 16,112 & 11 & 10,944 & 30 & 16,402 & 9 \\
\hline Low. & 104,422 & 9 & 112,192 & 13 & 47,164 & 12 & 61,840 & 11 \\
\hline High & 62,943 & 13 & 79,197 & 10 & 56,123 & 14 & 52,768 & 8 \\
\hline \multicolumn{9}{|l|}{ More than } \\
\hline 500,000 & 412,285 & 10 & 454,515 & 22 & 140,164 & 19 & 167,171 & 17 \\
\hline $\begin{array}{l} \\
\text { None ....... }\end{array}$ & $\begin{array}{r}412,203 \\
839\end{array}$ & 33 & $\begin{array}{r}45,517 \\
6,517\end{array}$ & -10 & $\begin{array}{r}140,104 \\
691\end{array}$ & 35 & $\begin{array}{r}1,615 \\
1,115\end{array}$ & -14 \\
\hline Low . & 230,770 & 6 & 135,545 & 18 & 67,862 & 12 & 54,991 & 15 \\
\hline High ......... & 180,676 & 16 & 312,453 & 24 & 71,611 & 26 & 110,565 & 19 \\
\hline \multicolumn{9}{|l|}{$\begin{array}{l}\text { By county } \\
\text { growth rate } 4\end{array}$} \\
\hline Low growth & 335,403 & 9 & 366,124 & 18 & 154,804 & 17 & 181,657 & 12 \\
\hline None .... & 9,172 & 25 & 17,527 & 2 & 5,482 & 26 & 11,617 & -1 \\
\hline Low. & 177,090 & 5 & 99,726 & 13 & 61,569 & 13 & 54,931 & 10 \\
\hline High & 149,141 & 13 & 248,871 & 22 & 87,753 & 19 & 115,109 & 14 \\
\hline High growth & 262,422 & 13 & 295,892 & 19 & 99,591 & 17 & 116,524 & 17 \\
\hline None ...... & 7,842 & 21 & 5,102 & 15 & 6,153 & 33 & 6,400 & 22 \\
\hline Low .. & $\begin{array}{r}158,102 \\
158,102\end{array}$ & $\begin{array}{r}21 \\
9\end{array}$ & $\begin{array}{r}148,011 \\
4\end{array}$ & 17 & 53,457 & 11 & $\begin{array}{r}0,900 \\
61,900\end{array}$ & 15 \\
\hline High & 94,478 & 19 & 142,779 & 20 & 39,981 & 23 & 48,224 & 20 \\
\hline \multicolumn{9}{|l|}{$\begin{array}{l}\text { By market } \\
\text { concentration } 5\end{array}$} \\
\hline Less than 1800 & 540,007 & 10 & 591,086 & 19 & 225,264 & 17 & 259,284 & 14 \\
\hline None ......... & 15,474 & 22 & 11,137 & 11 & $\begin{array}{r}9,861 \\
\quad\end{array}$ & 31 & 12,571 & 12 \\
\hline Low. & 312,379 & 7 & 203,546 & 15 & 106,089 & 11 & 95,015 & 11 \\
\hline High & 212,154 & 14 & 376,403 & 22 & 109,314 & 20 & 151,698 & 16 \\
\hline 1800 and more & $\begin{array}{r}57,818 \\
\end{array}$ & 15 & 70,930 & 11 & 29,131 & 22 & 38,897 & 10 \\
\hline None ........ & 3,540 & 27 & 11,492 & -1 & 1,774 & 26 & 5,446 & -2 \\
\hline Low .. & 22,813 & 3 & 44,191 & 16 & 8,937 & 22 & 21,816 & 18 \\
\hline High & 31,465 & 23 & 15,247 & 4 & 18,420 & 22 & 11,635 & 2 \\
\hline
\end{tabular}

1. Loans for which the borrowers' income was below 80 percent of the current year median family income of their MSA were classified as loans to lowerincome borrowers. Loans to black, Asian, Hispanic, Native American, and "other race" borrowers were classifed as loans to minorities.

Information on the census tract location of the property being purchased was used to determine which loans were originated in lower-income or minority neighborhoods. Loans for properties in census tracts whose 1990 median family income was less than 80 percent of the 1990 median income of their MSA were classified as loans to lower-income neighborhoods. Similarly, loans for properties in census tracts with more than 20 percent minority residents in 1990 were classified as loans to minority neighborhoods.

2. The three categories of consolidation are defined as the following: None-counties in which no organizations were involved in a consolidation;

consolidation and changes in their behavior in counties where they did not. Many banking organizations do considerable lending in areas where they do not have banking offices, often through affiliated mortgage and finance companies. In addition, institutions that are not affiliated with banking organizations and are not subject to the CRA-such as credit unions and mortgage and finance companies-extend many home purchase loans. Indeed, loans made by banking organizations in counties in which they had banking offices accounted for only 38 percent of overall home purchase lending in 1993 (derived from table 4).

low-counties in which the share of loans extended by organizations involved in consolidations was less than or equal to the median share of loans extended in all counties by organizations involved in consolidations for that period; and high-counties in which the share of loans extended by organizations involved in consolidations was greater than the median share of loans extended in all counties by organizations involved in consolidations for that period.

3. Population.

4. Counties with low growth rates are those where the 1993-95 growth in population was less than the median for all counties in the study. Counties with high growth rates are those where the growth in population was equal to or greater than the median.

5. Herfindahl-Hirschman index (HHI) level based on deposits at the beginning of each period.

The pattern of lending by banking organizations in counties where they operated banking offices is different from that of banking organizations in areas where they did not operate banking offices and from that of lending by other institutions (table 4). For example, over the 1993-97 period, banking organizations increased their overall lending 69 percent in areas where they did not have banking offices at the beginning of the period but only 8 percent in those counties where they did operate banking offices. There are similar differences in growth rates for the four borrower and neighborhood lending categories. 
4. Home purchase loans, by type and location of organization and by characteristic of borrower and neighborhood, 1993-97

\begin{tabular}{|c|c|c|c|c|c|c|c|c|c|c|}
\hline \multirow{3}{*}{$\begin{array}{l}\text { Type and location } \\
\text { of organization }\end{array}$} & \multicolumn{6}{|c|}{ Type of borrower ${ }^{1}$} & \multicolumn{4}{|c|}{ Type of neighborhood ${ }^{1}$} \\
\hline & \multicolumn{2}{|c|}{ All } & \multicolumn{2}{|c|}{ Minority } & \multicolumn{2}{|c|}{ Lower-income } & \multicolumn{2}{|c|}{ Minority } & \multicolumn{2}{|c|}{ Lower-income } \\
\hline & $\begin{array}{l}\text { Initial } \\
\text { number }\end{array}$ & $\begin{array}{l}\text { Percentage } \\
\text { change }\end{array}$ & $\begin{array}{l}\text { Initial } \\
\text { number }\end{array}$ & $\begin{array}{l}\text { Percentage } \\
\text { change }\end{array}$ & $\begin{array}{l}\text { Initial } \\
\text { number }\end{array}$ & $\begin{array}{l}\text { Percentage } \\
\text { change }\end{array}$ & $\begin{array}{l}\text { Initial } \\
\text { number }\end{array}$ & $\begin{array}{l}\text { Percentage } \\
\text { change }\end{array}$ & $\begin{array}{l}\text { Initial } \\
\text { number }\end{array}$ & $\begin{array}{l}\text { Percentage } \\
\text { change }\end{array}$ \\
\hline $\begin{array}{l}\text { Banking organizations } \\
\text { In counties with }\end{array}$ & $1,459,878$ & 31 & 208,178 & 63 & 402,724 & 27 & 315,803 & 40 & 151,768 & 32 \\
\hline branch offices ${ }^{2}$ & 925,236 & 8 & 131,739 & 29 & 259,676 & 4 & 193,251 & 15 & 104,356 & 4 \\
\hline In other counties ... & 534,642 & 69 & 76,439 & 122 & 143,048 & 68 & 122,552 & 79 & 47,322 & 93 \\
\hline Other institutions ${ }^{3}$ & 970,966 & 8 & 171,824 & 42 & 242,401 & 37 & 282,022 & 21 & 102,717 & 36 \\
\hline All lenders & $2,430,844$ & 21 & 380,002 & 53 & 645,125 & 31 & 597,825 & 31 & 254,395 & 33 \\
\hline $\begin{array}{l}\text { Note. Includes only owner-o } \\
\text { loans extended in MSAs. } \\
\text { 1. See note } 1 \text { to table } 3 \text {. } \\
\text { 2. Category includes loans } \\
\text { tions, and their mortgage and fi }\end{array}$ & all comn & rcial banks & avings & cia- & $\begin{array}{l}\text { ons are cor } \\
\text { hercial bank } \\
\text { ffice in that } \\
\text { 3. Catego } \\
\text { nions. }\end{array}$ & $\begin{array}{l}\text { sidered to ha } \\
\text { or savings ass } \\
\text { county. } \\
\text { y includes ind }\end{array}$ & $\begin{array}{l}\text { a branc } \\
\text { ciation c } \\
\text { pendent }\end{array}$ & $\begin{array}{l}\text { fice in a co } \\
\text { tonent of the } \\
\text { tgage and fin }\end{array}$ & $\begin{array}{l}\text { ty only } \\
\text { rganizat } \\
\text { ice com }\end{array}$ & $\begin{array}{l}\text { nere the com- } \\
\text { has a branch } \\
\text { hies and credit }\end{array}$ \\
\hline
\end{tabular}

\section{Measuring the Effects of Consolidation}

The unit of observation in measuring the effects of consolidation in the analysis in this section is the banking organization-county combination. Each banking organization is linked with each county in every metropolitan area-a total of 726 counties. Thus, each banking organization potentially has 726 distinct observations. However, a banking organization-county combination is included in the sample only if the organization had a CRA obligation in the county. Such an obligation is considered to exist if any banking-institution component (commercial bank or savings association) of a banking organization operated a banking office in the county at the beginning of the study period. A single organization may appear in the sample several times if it had offices in more than one county, as was true in 1993, for instance, for nearly 30 percent of the banking organizations (appendix table A.1). The sample was further restricted to include only those combinations in which the organization extended ten loans or more in the county in the first year of the analytical period. $^{22}$

To assess the effects of consolidation on home purchase lending by banking organizations, we compare the behavior of organizations that were involved in consolidation in a county with that of organizations that were not. As before, an organization is considered to have undergone a consolidation in a county only if a banking-institution component of the organization that was operating a banking

22. This restriction removes only about 1 percent of the home purchase loans from the sample. office in the county was acquired during the study period. Those combinations involved in consolidation are further subdivided according to the type of consolidation. These decompositions allow for an assessment of whether and how consolidation in banking has been associated with changes in overall lending and lending to lower-income and minority borrowers and neighborhoods. Because economic theory suggests that the geographic proximity of the acquiring and acquired organizations may influence subsequent lending patterns, we divide organizationcounty combinations involved in consolidation into three types according to the location of the offices of the acquiring component: (1) consolidations in which the acquiring as well as the acquired components of the organizations operated offices in the county (within-county consolidations), (2) consolidations in which the acquiring component operated an office in the MSA containing the county but not in the county (within-MSA-not-in-county consolidations), and (3) consolidations in which the acquiring component did not operate offices in either the county or its MSA (out-of-MSA consolidations).

Economic theory further suggests that the size of the organizations involved in a consolidation may affect lending activity. Thus, for the current analysis, we group consolidations according to the size (in assets) of the acquiring and the acquired organization (see the appendix): (1) a small organization (assets of less than \$250 million) acquiring another small organization, (2) a medium-sized organization (assets between $\$ 250$ million and $\$ 10$ billion) acquiring a small organization, (3) a medium-sized organization acquiring another medium-sized organization, (4) a large organization (assets greater than $\$ 10$ billion) acquiring a small organization, (5) a large organization acquiring a medium-sized organization, and 
(6) a large organization acquiring another large organization.

The approach taken here employs performance standards often used in previous research on home mortgage lending issues. ${ }^{23}$ They are also used in evaluating the CRA record of banking organizations. These measures are (1) the change in the number of loans an organization makes in a county overall and to lower-income and minority borrowers and neighborhoods, (2) changes in an organization's share of the total number of loans in a county overall and to lower-income and minority borrowers and neighborhoods in each of the organization's local communities (market share), and (3) changes in the share of an organization's own loan activity in a county that is composed of such lending (portfolio share). (See box "Performance Standards Used to Measure the Effects of Consolidation at the Organization Level.") All three measures are based on numbers of loans, although CRA examiners also consider the dollar amount of lending in using these measures. Changes in the lending activity of consolidating organizations are computed by comparing lending by the merged organization at the end of the period with the combined lending activity of the component parts of the merged organization (called a "pro forma" organization) at the beginning of the period. ${ }^{24}$

Because we want to characterize the behavior of the "typical" banking organization, we focus on median values in the market share and portfolio share analyses. The median is preferred because the mean may be greatly influenced by extreme values, either positive or negative. Median values are sensitive, however, to the number of banking organization-county combinations that had no lending in a particular borrower or neighborhood category over the analytical period. For some categories, the number of such combinations is relatively large, which can give a misleading indication of the effects of consolidation on organizations active in certain types of lending (table 5). ${ }^{25}$ Thus, in calculating

23. See, for example, Glenn B. Canner, Wayne Passmore, and Brian J. Surette, "Distribution of Credit Risk among Providers of Mortgages to Lower-Income and Minority Homebuyers," Federal Reserve Bulletin, vol. 82 (December 1996), pp. 1077-1102.

24. The sum includes all lending in the county by all component parts of the organization in the first period, including those components that did not have banking offices or CRA obligations.

25. For example, in each of the sample periods about 27 percent of the banking organization-county combinations had no lending to minority neighborhoods. This result likely reflects a relatively large number of smaller banks located in counties with small numbers of minority neighborhoods. median values, we exclude all cases in which a banking organization extended no loans in a particular borrower or neighborhood category in a county. For example, if a bank extended no loans to lower-

\section{Performance Standards Used to Measure the Effects of Consolidation at the Organization Level}

Three performance standards are used to measure the effects of consolidation: the number of home purchase loans, market share, and portfolio share. Three measures are used because, while each may provide insight into home purchase lending in a market, each also has some shortcomings. In combination, they provide a more complete picture of trends in lending.

The number of home purchase loans an organization makes is one indicator of the level of service it provides to a local area. Changes in this measure show whether lending is increasing or decreasing. However, exclusive consideration of this measure may lead to misleading inferences. The number of loans does not provide an indication of how well an organization is performing relative to other organizations in a given market. It also fails to show an organization's own relative commitment to certain types of lending.

The second measure, market share, addresses the first of these limitations. Changes in an organization's market share of home purchase loans provide a measure of how its activity is changing relative to the market as a whole. Increases (decreases) in market share indicate that an organization has a greater (lesser) presence in a given type of lending. Trends in market share do not necessarily mirror trends in the number of loans. For example, an organization's market share can decline even while the number of its loans increases if other organizations increase their levels of lending more rapidly. The market share measure, however, is not without its own limitations as a measure of performance. Most prominently, an organization's market share may be greatly influenced by the actions of other competitors in the market and changes in the demand for home purchase loans, both of which are largely outside its control.

The portfolio share measure provides another gauge of an organization's relative experience with a given type of lending. Like the market share measure, trends in portfolio share can be different from trends in the number of loans. However, unlike the market share measure, the portfolio share measure tends not to be overly sensitive to the activities of market competitors. The limitation of this measure is that an organization may have a growing portfolio share of lending to a given population yet a shrinking presence overall in lending to that population, measured either in terms of absolute numbers of loans or market share. 
5. Percentage of banking organization-county combinations with no lending to minority and lower-income borrowers and neighborhoods, 1993-95 and 1995-97

\begin{tabular}{|c|c|c|c|c|c|c|c|c|}
\hline \multirow{3}{*}{ Category } & \multicolumn{4}{|c|}{ Type of borrower ${ }^{1}$} & \multicolumn{4}{|c|}{ Type of neighborhood ${ }^{1}$} \\
\hline & \multicolumn{2}{|c|}{ Minority } & \multicolumn{2}{|c|}{ Lower-income } & \multicolumn{2}{|c|}{ Minority } & \multicolumn{2}{|c|}{ Lower-income } \\
\hline & 1993-95 & 1995-97 & 1993-95 & 1995-97 & 1993-95 & 1995-97 & $1993-95$ & $1995-97$ \\
\hline No lending $\ldots \ldots \ldots \ldots \ldots \ldots \ldots \ldots \ldots \ldots$ & 10.6 & 9.7 & .4 & .5 & 27.1 & 27.5 & 14.8 & 15.6 \\
\hline No lending and involved in consolidations & 1.0 & .8 & .1 & .1 & 4.2 & 3.4 & 2.1 & 2.0 \\
\hline $\begin{array}{l}\text { Memo } \\
\text { Number of banking organization- } \\
\quad \text { county combinations } . . . . . .\end{array}$ & 7,143 & 7,100 & 7,143 & 7,100 & 7,143 & 7,100 & 7,143 & 7,100 \\
\hline
\end{tabular}

1. See note 1 to table 3 .

income applicants over 1993-95, it is not considered in calculating the median change in market share of lending to lower-income borrowers during that period (that is, it is not considered to have had a 0 percent change in its market share). ${ }^{26}$

It is important to emphasize that the patterns found in this analysis may differ from those in the previous section. In this analysis, we track changes in home purchase lending for banking organizations only in the counties in which they operated offices at the beginning of each analytical period. These changes do not necessarily reflect total changes in an organization's lending, as an organization may have expanded both its CRA obligations and its lending into new markets over time. As with the preceding analysis, the discussion emphasizes only those relationships that are robust after considering other factors that may have influenced home purchase lending patterns.

\section{Consolidation and Lending by Banking Organizations in Counties Where They Operate Offices}

A simple count of the number of banking organization-county combinations involved in consolidation provides a perspective on the extent of consolidation in the banking industry over our periods of analysis. Over each time period we analyze, a relatively small percentage of banking organization-county combinations were involved in consolidation-for example, only 18 percent of the organization-county combinations in the sample over

26. While this procedure reduces the sample, it does not result in a significant decline in the number of banking organization-county combinations involved in consolidation that were included in the sample. Very few organizations that had no lending in either period were involved in a consolidation. For example, over 1995-97, less than 1 percent of all banking organization-county combinations in the sample that were involved in consolidation made no loans to minority borrowers or to lower-income borrowers. the 1995-97 period were involved in a consolidation (table 6). However, these tended to include organizations with relatively large numbers of home purchase loans, as they accounted for almost 30 percent of all lending in counties by banking organizations with CRA obligations in those counties (derived from table 7).

Most banking organization-county combinations involved in consolidation were involved in either within-county consolidations or out-of-MSA consolidations-90 percent over 1993-95 (derived from table 6). In addition, a majority of the banking organization-county combinations involved in mergers involved large acquiring institutions -54 percent over 1993-95 (derived from table 6). These organizations extended most of the home purchase loans-

6. Distribution of banking organization-county combinations, by level of consolidation activity and size and location of banking organization, 1993-95 and 1995-97

\begin{tabular}{|c|c|c|}
\hline $\begin{array}{l}\text { Consolidation category for } \\
\text { banking organization- } \\
\text { county combinations }\end{array}$ & 1993-95 & 1995-97 \\
\hline $\begin{array}{l}\text { No consolidation ..................... } \\
\text { By size of banking organization }{ }^{1}\end{array}$ & 5,850 & 5,800 \\
\hline Small $\ldots \ldots \ldots \ldots \ldots \ldots \ldots \ldots$ & 2,047 & 1,813 \\
\hline Medium & 2,237 & 2,168 \\
\hline Large .. & 1,566 & 1,819 \\
\hline Any consolidation & 1,293 & 1,300 \\
\hline By location & & \\
\hline Within county & 603 & 608 \\
\hline Within MSA, not in county & 125 & 96 \\
\hline Out of MSA $\ldots \ldots \ldots \ldots$ & 565 & 596 \\
\hline By size of banking organization ${ }^{1}$ & & \\
\hline Small acquiring small $\ldots \ldots \ldots \ldots$ & 78 & 69 \\
\hline Medium acquiring small & 211 & 184 \\
\hline Medium acquiring medium & 300 & 197 \\
\hline Large acquiring small ..... & 71 & 51 \\
\hline Large acquiring medium & 314 & 318 \\
\hline Large acquiring large .... & 319 & 481 \\
\hline $\begin{array}{c}\text { All banking organization- } \\
\text { county combinations }\end{array}$ & 7,143 & 7,100 \\
\hline
\end{tabular}

1. Size categories are the following: A small organization has assets of less than $\$ 250$ million; a medium-sized organization has assets between $\$ 250$ million and \$10 billion; and a large organization has assets of more than $\$ 10$ billion. 
about 68 percent over 1993-95-originated by banking organization-county combinations involved in consolidation (derived from table 7).

Changes in the Level and Market Share of Home Purchase Lending

In stark contrast to the analysis of the effects of consolidation on home purchase lending at the market level, which found no consistent relationships between consolidation and changes in home purchase lending, consolidation does appear to be related to changes in home purchase lending when the effects are examined at the organizational level. Again the focus is on lending by banking organizations in those counties in which they operated banking offices.

Banking organization-county combinations that were involved in consolidation consistently showed less growth (or more decline) in the number of home purchase loans they originated than banking organization-county combinations that were not involved in consolidation. Moreover, the growth in home purchase lending by both groups was generally less than the growth in total lending in metropolitan areas. Although the growth rates of total lending for all mortgage lending organizations were 3 percent and 17 percent in 1993-95 and 1995-97 respectively (derived from table 1), the number of loans extended by the banking organization-county combinations in our sample that were involved in consolidation declined about 14 percent in each period while the number of loans extended by those combinations in our sample not involved in consolidation increased 3 percent in both periods (table 7).

These relative relationships generally hold for overall lending and for lending to the four borrower and neighborhood categories and in both time periods, although not all differences are statistically significant. The market share of home purchase loans in a county extended by the typical consolidating organization with an office in that county (that is, the median banking organization-county combination involved in a consolidation) declined substantially in both years, and by more than that of the typical non-consolidating organization with an office in that county (table 8). This result indicates that the patterns shown in table 7 are not driven by the behavior of just a few large organizations but rather reflect the experiences of the typical organization.

When banking organization-county combinations involved in a consolidation are distributed according to the type of consolidation that took place, few consistent patterns appear, with two notable exceptions. Grouping banking organization-county combinations according to the location of offices of the acquiring firm, we find that within-county consolidations are associated with larger growth (or smaller declines) in the number of loans extended overall and to the four borrower and neighborhood categories compared with other types of consolidation (table 7). For example, although the overall amount of lending by banking organization-county combinations involved in out-of-MSA consolidations declined 27 percent over 1993-95, the decline was only 9 percent among those combinations involved in within-county consolidations.

Banking organization-county combinations are also grouped according to the size of the acquiring and acquired organizations. The most consistent results occur among those consolidations in which the acquirer was large, although the differences were not always statistically significant. Acquisitions of small organizations by large organizations generally are associated with the largest increases in the number of loans extended overall and to the four borrower and neighborhood groups. Acquisitions of large organizations by other large organizations generally are associated with relatively large declines in lending.

The finding that consolidation is consistently associated with declines in lending-both overall and across the four borrower and neighborhood groupsappears to support the view that consolidation results in a reduction in home purchase lending, possibly because of a shift away from local decisionmaking, anticompetitive effects, or the acquisition of savings associations by banking organizations. However, some results are inconsistent with these explanations.

A reduction of the influence of local decisionmaking would suggest that consolidations in which a large organization acquires a small organization might be associated with larger declines (or less growth) in lending than consolidations in which both the acquirer and acquired organization are large. However the reverse is true-consolidations in which large organizations acquired other large organizations are generally associated with larger declines (or less growth) than consolidations in which large organizations acquired small organizations. Anticompetitive effects would most likely be observed in within-county consolidations; yet these are not associated with a disproportionate decline in lending. It should be noted, however, that the finding that outof-MSA consolidations show the largest declines in lending is consistent with a shift away from local 
7. Home purchase loans by banking organization-county combinations, by level of consolidation activity and size and location of banking organization, 1993-95 and 1995-97

\begin{tabular}{|c|c|c|c|c|c|c|c|c|c|c|c|c|}
\hline \multirow{4}{*}{$\begin{array}{c}\text { Consolidation } \\
\text { category } \\
\text { for banking } \\
\text { organization- } \\
\text { county } \\
\text { combinations }\end{array}$} & \multirow{2}{*}{\multicolumn{4}{|c|}{ All borrowers }} & \multicolumn{8}{|c|}{ Type of borrower ${ }^{1}$} \\
\hline & & & & & & Min & rity & & & Lower- & ncome & \\
\hline & \multicolumn{2}{|c|}{$1993-95$} & \multicolumn{2}{|c|}{$1995-97$} & \multicolumn{2}{|c|}{ 1993-95 } & \multicolumn{2}{|c|}{$1995-97$} & \multicolumn{2}{|c|}{ 1993-95 } & \multicolumn{2}{|c|}{ 1995-97 } \\
\hline & $\begin{array}{c}\text { Initial } \\
\text { number }\end{array}$ & $\begin{array}{c}\text { Percentage } \\
\text { change }\end{array}$ & $\begin{array}{l}\text { Initial } \\
\text { number }\end{array}$ & $\begin{array}{c}\text { Percentage } \\
\text { change }\end{array}$ & $\begin{array}{l}\text { Initial } \\
\text { number }\end{array}$ & $\begin{array}{c}\text { Percentage } \\
\text { change }\end{array}$ & $\begin{array}{l}\text { Initial } \\
\text { number }\end{array}$ & $\begin{array}{c}\text { Percentage } \\
\text { change }\end{array}$ & $\begin{array}{l}\text { Initial } \\
\text { number }\end{array}$ & $\begin{array}{c}\text { Percentage } \\
\text { change }\end{array}$ & $\begin{array}{l}\text { Initial } \\
\text { number }\end{array}$ & $\begin{array}{l}\text { Percentage } \\
\text { change }\end{array}$ \\
\hline $\begin{array}{l}\text { No consolidation } \\
\text { By size }\end{array}$ & 653,665 & 3 & 692,296 & 3 & 92,299 & 26 & 115,623 & -2 & 181,881 & -2 & 190,323 & 1 \\
\hline Small & 114,177 & -7 & 90,406 & 7 & 12,151 & 11 & 11,383 & 11 & 30,923 & -6 & 24,961 & 14 \\
\hline Medium ...... & 264,289 & 2 & 244,983 & 9 & 32,038 & 28 & 33,624 & 4 & 71,006 & -1 & 62,541 & 11 \\
\hline Large $\ldots \ldots \ldots$ & 275,199 & 7 & 356,907 & -2 & 48,110 & 29 & 70,616 & -8 & 79,952 & -2 & 102,821 & -9 \\
\hline Any consolidation & 278,519 & -15 & 289,948 & -13 & 39,072 & 12 & 58,430 & -11 & 78,589 & -13 & 73,963 & -6 \\
\hline Within county & 182,301 & -9 & 188,107 & -8 & 27,898 & 15 & 43,315 & -8 & 50,613 & -8 & 46,706 & 0 \\
\hline $\begin{array}{c}\text { not in } \\
\text { county } \ldots \\
\text { Out of MSA } \ldots\end{array}$ & $\begin{array}{l}10,949 \\
85,269\end{array}$ & $\begin{array}{l}-17 \\
-27\end{array}$ & $\begin{array}{r}8,295 \\
93,546\end{array}$ & $\begin{array}{l}-23 \\
-23\end{array}$ & $\begin{array}{r}926 \\
10,248\end{array}$ & $\begin{array}{r}66 \\
0\end{array}$ & $\begin{array}{r}1,358 \\
13,757\end{array}$ & $\begin{array}{l}-34 \\
-20\end{array}$ & $\begin{array}{r}3,591 \\
24,385\end{array}$ & $\begin{array}{r}-8 \\
-24\end{array}$ & $\begin{array}{r}2,221 \\
25,036\end{array}$ & $\begin{array}{l}-20 \\
-18\end{array}$ \\
\hline $\begin{array}{l}\text { By size }{ }^{2} \\
\text { Small } \\
\quad \text { acquiring } \\
\text { small } \ldots . . . \\
\text { Medium }\end{array}$ & 4,717 & -19 & 5,206 & -17 & 882 & -43 & 729 & -21 & 1,215 & -20 & 1,472 & -10 \\
\hline $\begin{array}{l}\quad \begin{array}{l}\text { acquiring } \\
\text { small } \ldots . . .\end{array} \\
\text { Medium }\end{array}$ & 24,513 & -1 & 19,983 & -7 & 3,119 & 31 & 3,509 & -1 & 6,351 & 7 & 5,268 & 6 \\
\hline $\begin{array}{l}\text { acquiring } \\
\text { medium .. } \\
\text { Large }\end{array}$ & 59,931 & 1 & 35,870 & -17 & 6,543 & 20 & 5,268 & -21 & 15,092 & -1 & 9,389 & -9 \\
\hline $\begin{array}{l}\text { acquiring } \\
\text { small } \ldots . . . \\
\text { Large }\end{array}$ & 22,769 & 22 & 14,149 & 5 & 4,770 & 45 & 2,442 & -3 & 6,549 & 8 & 4,424 & 7 \\
\hline $\begin{array}{l}\text { acquiring } \\
\text { medium .. } \\
\text { Large }\end{array}$ & 93,172 & -27 & 84,569 & -8 & 14,370 & -5 & 16,873 & -6 & 26,366 & -26 & 22,321 & -1 \\
\hline large ..... & 73,417 & -29 & 130,171 & -18 & 9,388 & 17 & 29,609 & -14 & 23,016 & -17 & 31,089 & -13 \\
\hline
\end{tabular}

decisionmaking. Finally, those consolidations involving the acquisition of savings associations by banking organizations, which, as noted earlier, could potentially reduce home purchase lending, show virtually the same lending patterns as other consolidations.

Also, these results cannot readily be explained by a reduction in overall lending by organizations that were involved in consolidation. Overall home purchase lending by these organizations grew 16 percent in 1993-95 and 22 percent during 1995-97 (not shown in tables). Virtually all of this growth was in counties in which the organizations did not have banking offices. The growth in these institutions' home purchase lending in these out-of-market areas was 57 percent over 1993-95 and 69 percent over 1995-97 (not shown in tables). Moreover, the growth in out-of-market lending by these consolidating banking organizations substantially exceeded the growth in home purchase lending by other groups of market participants.

The reduction of home purchase lending by consolidating banking organizations in those counties in which they operated offices appears to be part of an overall trend toward geographic diversification. This diversification may have been fueled by the acquisition of large, previously independent mortgage banking organizations and an expansion of activity by previously affiliated mortgage and finance companies. Also, increased standardization in the home purchase loan market, facilitated in part by developments in the secondary market and the growing use of automated underwriting, may have reduced the need for banking organizations to maintain a local presence to originate home purchase loans.

\section{Changes in Portfolio Shares}

Results using the portfolio share measure provide a different picture of the effect of consolidation on home purchase lending than those using either market share measures or counts of loans (table 9). Using market share measures or counts of loans showed that organizations involved in consolidation typically reduced their overall lending and lending to the four borrower and neighborhood groups in those counties in which they had banking offices. The portfolio 


\section{7.-Continued}

\begin{tabular}{|c|c|c|c|c|c|c|c|c|}
\hline \multirow{4}{*}{$\begin{array}{l}\text { Consolidation } \\
\text { category } \\
\text { for banking } \\
\text { organization- } \\
\text { county } \\
\text { combinations }\end{array}$} & \multicolumn{8}{|c|}{ Type of neighborhood ${ }^{1}$} \\
\hline & \multicolumn{4}{|c|}{ Minority } & \multicolumn{4}{|c|}{ Lower-income } \\
\hline & \multicolumn{2}{|c|}{ 1993-95 } & \multicolumn{2}{|c|}{$1995-97$} & \multicolumn{2}{|c|}{ 1993-95 } & \multicolumn{2}{|c|}{ 1995-97 } \\
\hline & $\begin{array}{c}\text { Initial } \\
\text { number }\end{array}$ & $\begin{array}{l}\text { Percentage } \\
\text { change }\end{array}$ & $\begin{array}{c}\text { Initial } \\
\text { number }\end{array}$ & $\begin{array}{l}\text { Percentage } \\
\text { change }\end{array}$ & $\begin{array}{l}\text { Initial } \\
\text { number }\end{array}$ & $\begin{array}{l}\text { Percentage } \\
\text { change }\end{array}$ & $\begin{array}{c}\text { Initial } \\
\text { number }\end{array}$ & $\begin{array}{l}\text { Percentage } \\
\text { change }\end{array}$ \\
\hline $\begin{array}{l}\text { No consolidation } \\
\text { By size }^{2}\end{array}$ & 137,940 & 9 & 148,093 & 0 & 73,411 & 9 & 84,082 & -10 \\
\hline Small .......... & 20,995 & -6 & 16,260 & 8 & 12,985 & 0 & 11,237 & 2 \\
\hline $\begin{array}{l}\text { Medium ....... } \\
\text { Large .......... }\end{array}$ & $\begin{array}{l}46,076 \\
70,869\end{array}$ & $\begin{array}{r}9 \\
14\end{array}$ & $\begin{array}{l}41,892 \\
89,941\end{array}$ & $\begin{array}{r}4 \\
-3\end{array}$ & $\begin{array}{l}26,081 \\
34,345\end{array}$ & $\begin{array}{r}14 \\
9\end{array}$ & $\begin{array}{l}26,162 \\
46,683\end{array}$ & $\begin{array}{r}-3 \\
-17\end{array}$ \\
\hline Any consolidation & 54,650 & -4 & 74,072 & -9 & 30,379 & 0 & 33,626 & -13 \\
\hline $\begin{array}{l}\text { Within county } \\
\text { Within MSA, }\end{array}$ & 36,945 & 2 & 54,771 & -6 & 19,902 & 5 & 22,961 & -8 \\
\hline $\begin{array}{c}\text { not in } \\
\text { county } \\
\text { Out of MSA }\end{array}$ & $\begin{array}{r}1,220 \\
16,485\end{array}$ & $\begin{array}{r}26 \\
-18\end{array}$ & $\begin{array}{r}1,766 \\
17,535\end{array}$ & $\begin{array}{l}-27 \\
-16\end{array}$ & $\begin{array}{l}1,319 \\
9,158\end{array}$ & $\begin{array}{r}20 \\
-12\end{array}$ & $\begin{array}{r}999 \\
9,666\end{array}$ & $\begin{array}{l}-27 \\
-25\end{array}$ \\
\hline $\begin{array}{l}\text { By size } e^{2} \\
\begin{array}{l}\text { Small } \\
\quad \text { acquiring } \\
\text { small ..... }\end{array}\end{array}$ & 1,305 & -49 & 1,237 & -35 & 617 & -19 & 652 & -29 \\
\hline $\begin{array}{l}\text { Medium } \\
\text { acquiring } \\
\text { small .... } \\
\text { Medium }\end{array}$ & 4,307 & 8 & 5,373 & -10 & 2,524 & 10 & 2,319 & -7 \\
\hline $\begin{array}{l}\text { acquiring } \\
\text { medium . } \\
\text { Large }\end{array}$ & 9,840 & -3 & 6,045 & -23 & 5,736 & 2 & 3,826 & -15 \\
\hline 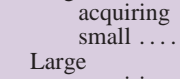 & 6,994 & 29 & 2,845 & 3 & 3,149 & 16 & 1,903 & 7 \\
\hline 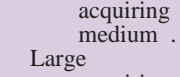 & 20,685 & -13 & 20,872 & -8 & 9,562 & -9 & 8,977 & -10 \\
\hline $\begin{array}{l}\text { acquiring } \\
\text { large ..... }\end{array}$ & 11,519 & -6 & 37,700 & -7 & 8,791 & 1 & 15,949 & -18 \\
\hline
\end{tabular}

share measure shows that this reduction did not disproportionately affect lending to lower-income and minority borrowers and neighborhoods. Indeed, the portfolio share measure shows that the typical consolidating organization generally increased the proportion of loans extended to each of the four borrower and neighborhood groups. These changes are generally larger (or less negative) than the changes observed among banking organization-county combinations not involved in consolidation. For example, the change in the portfolio share for lending to minority borrowers for the typical organization involved in a consolidation was 31 percent compared with only 21 percent for the typical organization not involved in a consolidation during 1993-95. When banking organization-county combinations involved in consolidation are distributed according to the type of consolidation (by either location or size of the acquiring and acquired organization), few consistent patterns emerge over the two periods.

These results are consistent with the view that the CRA has been effective in encouraging banking organizations, particularly those involved in consolida- tion, to serve lower-income and minority borrowers and neighborhoods. The data, however, are not sufficient to provide a complete evaluation of the effects of the CRA in this regard. For example, no information is available on the prices charged for loans or on whether they were underwritten using special guidelines for affordable lending programs. Loans to lower-income and minority borrowers and neighborhoods may be more difficult to underwrite and thus benefit more from a local office presence than from any particular pressures due to the CRA. Moreover, banking organizations have also increased their lending to lower-income and minority borrowers in counties where they have no banking offices.

\section{APPENDIX: CONSTRUCTION OF THE DATABASE}

The data used in this article combine information on branch office location, home purchase loan originations, and records of bank structure, failures, mergers, and acquisitions from several sources. (See table A.1 for a description of the study sample.) 
8. Market share of home purchase lending by banking organization-county combinations, by level of consolidation activity and size and location of banking organization, 1993-95 and 1995-97

Percent

\begin{tabular}{|c|c|c|c|c|c|c|c|c|c|c|c|c|}
\hline \multirow{4}{*}{$\begin{array}{l}\text { Consolidation } \\
\text { category } \\
\text { for banking } \\
\text { organization- } \\
\text { county } \\
\text { combinations }\end{array}$} & \multirow{2}{*}{\multicolumn{4}{|c|}{ All borrowers }} & \multicolumn{8}{|c|}{ Type of borrower ${ }^{1}$} \\
\hline & & & & & \multicolumn{4}{|c|}{ Minority } & \multicolumn{4}{|c|}{ Lower-income } \\
\hline & \multicolumn{2}{|c|}{$1993-95$} & \multicolumn{2}{|c|}{$1995-97$} & \multicolumn{2}{|c|}{$1993-95$} & \multicolumn{2}{|c|}{$1995-97$} & \multicolumn{2}{|c|}{$1993-95$} & \multicolumn{2}{|c|}{ 1995-97 } \\
\hline & $\begin{array}{l}\text { Initial } \\
\text { share }\end{array}$ & $\begin{array}{c}\text { Percentage } \\
\text { change }\end{array}$ & $\begin{array}{l}\text { Initial } \\
\text { share }\end{array}$ & $\begin{array}{c}\text { Percentage } \\
\text { change }\end{array}$ & $\begin{array}{l}\text { Initial } \\
\text { share }\end{array}$ & $\begin{array}{c}\text { Percentage } \\
\text { change }\end{array}$ & $\begin{array}{l}\text { Initial } \\
\text { share }\end{array}$ & $\begin{array}{c}\text { Percentage } \\
\text { change }\end{array}$ & $\begin{array}{l}\text { Initial } \\
\text { share }\end{array}$ & $\begin{array}{c}\text { Percentage } \\
\text { change }\end{array}$ & $\begin{array}{l}\text { Initial } \\
\text { share }\end{array}$ & $\begin{array}{l}\text { Percentage } \\
\text { change }\end{array}$ \\
\hline No consolidation & 2.0 & -7 & 2.2 & -13 & 1.1 & -9 & 1.3 & -17 & 1.9 & -13 & 2.0 & -16 \\
\hline $\begin{array}{l}\text { Small ......... } \\
\text { Medium ....... } \\
\text { Large ...... }\end{array}$ & $\begin{array}{l}1.2 \\
2.0 \\
3.0\end{array}$ & $\begin{array}{r}-16 \\
-4 \\
-1\end{array}$ & $\begin{array}{l}1.1 \\
1.9 \\
3.6\end{array}$ & $\begin{array}{r}-11 \\
-5 \\
-22\end{array}$ & $\begin{array}{r}.3 \\
1.2 \\
2.7\end{array}$ & $\begin{array}{r}-21 \\
-3 \\
-4\end{array}$ & $\begin{array}{r}.3 \\
1.2 \\
3.3\end{array}$ & $\begin{array}{r}-16 \\
-7 \\
-26\end{array}$ & $\begin{array}{l}1.2 \\
1.9 \\
3.3\end{array}$ & $\begin{array}{r}-19 \\
-8 \\
-10\end{array}$ & $\begin{array}{l}1.1 \\
1.7 \\
3.5\end{array}$ & $\begin{array}{r}-12 \\
-9 \\
-28\end{array}$ \\
\hline Any consolidation & 3.5 & -24 & 3.6 & -27 & 2.6 & -19 & 3.0 & -30 & 3.5 & -24 & 3.4 & -28 \\
\hline $\begin{array}{c}\text { By location } \\
\text { Within county } \\
\text { Within MSA, } \\
\text { not in }\end{array}$ & 4.4 & -17 & 4.3 & -27 & 3.6 & -13 & 3.8 & -28 & 4.1 & -14 & 4.1 & -26 \\
\hline $\begin{array}{r}\text { county } \\
\text { Out of MSA }\end{array}$ & $\begin{array}{l}2.5 \\
3.1\end{array}$ & $\begin{array}{l}-34 \\
-31\end{array}$ & $\begin{array}{l}2.8 \\
3.1\end{array}$ & $\begin{array}{l}-36 \\
-28\end{array}$ & $\begin{array}{r}.7 \\
2.2\end{array}$ & $\begin{array}{l}-16 \\
-27\end{array}$ & $\begin{array}{l}2.0 \\
2.6\end{array}$ & $\begin{array}{l}-48 \\
-30\end{array}$ & $\begin{array}{l}2.9 \\
2.9\end{array}$ & $\begin{array}{l}-33 \\
-32\end{array}$ & $\begin{array}{l}2.6 \\
2.8\end{array}$ & $\begin{array}{l}-36 \\
-28\end{array}$ \\
\hline $\begin{array}{l}\text { By size }{ }^{2} \\
\text { Small } \\
\quad \text { acquiring } \\
\text { small .... }\end{array}$ & .7 & -21 & .9 & -33 & .2 & -24 & 0.5 & -36 & .8 & -21 & .9 & -37 \\
\hline $\begin{array}{l}\text { Medium } \\
\text { acquiring } \\
\text { small } \ldots \\
\text { Medium }\end{array}$ & 2.1 & -15 & 1.7 & -21 & 1.3 & -12 & .8 & -18 & 2.1 & -7 & 1.4 & -15 \\
\hline $\begin{array}{l}\text { acquiring } \\
\text { medium . } \\
\text { Large }\end{array}$ & 3.4 & -13 & 3.0 & -30 & 2.2 & -7 & 2.1 & -31 & 3.1 & -6 & 2.6 & -28 \\
\hline $\begin{array}{l}\text { acquiring } \\
\text { small .... } \\
\text { Large }\end{array}$ & 3.8 & -4 & 2.5 & -18 & 4.3 & -3 & 1.7 & -20 & 4.1 & -14 & 1.9 & -25 \\
\hline $\begin{array}{l}\text { acquiring } \\
\text { medium . } \\
\text { Large }\end{array}$ & 4.4 & -30 & 5.1 & -20 & 3.3 & -29 & 4.4 & -20 & 4.1 & -33 & 5.0 & -19 \\
\hline $\begin{array}{l}\text { acquiring } \\
\text { large ..... }\end{array}$ & 4.9 & -37 & 4.1 & -32 & 4.0 & -29 & 4.0 & -37 & 4.5 & -31 & 3.9 & -34 \\
\hline
\end{tabular}

9. Portfolio share of home purchase lending by banking organization-county combinations to minority and lower-income borrowers and neighborhoods, by level of consolidation activity and size and location of banking organization, 1993-95 and 1995-97

Percent

\begin{tabular}{|c|c|c|c|c|c|c|c|c|}
\hline \multirow{4}{*}{$\begin{array}{l}\text { Consolidation category } \\
\text { for banking organization- } \\
\text { county combinations }\end{array}$} & \multicolumn{8}{|c|}{ Type of borrower ${ }^{1}$} \\
\hline & \multicolumn{4}{|c|}{ Minority } & \multicolumn{4}{|c|}{ Lower-income } \\
\hline & \multicolumn{2}{|c|}{$1993-95$} & \multicolumn{2}{|c|}{ 1995-97 } & \multicolumn{2}{|c|}{ 1993-95 } & \multicolumn{2}{|c|}{$1995-97$} \\
\hline & $\begin{array}{l}\text { Initial } \\
\text { share }\end{array}$ & $\begin{array}{c}\text { Percentage } \\
\text { change }\end{array}$ & $\begin{array}{l}\text { Initial } \\
\text { share }\end{array}$ & $\begin{array}{c}\text { Percentage } \\
\text { change }\end{array}$ & $\begin{array}{l}\text { Initial } \\
\text { share }\end{array}$ & $\begin{array}{c}\text { Percentage } \\
\text { change }\end{array}$ & $\begin{array}{l}\text { Initial } \\
\text { share }\end{array}$ & $\begin{array}{l}\text { Percentage } \\
\text { change }\end{array}$ \\
\hline $\begin{array}{l}\text { No consolidation } \\
B y \text { size }^{2}\end{array}$ & 6.3 & 21 & 7.5 & -6 & 26.2 & -5 & 26.2 & 5 \\
\hline Small .. & 3.4 & 20 & 4.3 & -6 & 27.4 & -3 & 28.0 & 5 \\
\hline Medium & 6.3 & 25 & 7.5 & -6 & 24.8 & -5 & 24.2 & 6 \\
\hline Large & 9.7 & 19 & 10.6 & -6 & 26.7 & -6 & 26.7 & 2 \\
\hline $\begin{array}{l}\text { Any consolidation } \\
\text { By location }\end{array}$ & 7.2 & 31 & 11.1 & -5 & 26.1 & 3 & 25.0 & 8 \\
\hline Within county & 8.3 & 28 & 13.9 & -3 & 26.7 & 4 & 23.5 & 8 \\
\hline Within MSA, not in county & 4.4 & 45 & 8.8 & -33 & 26.1 & 4 & 25.0 & 9 \\
\hline Out of MSA & 6.9 & 31 & 9.2 & -6 & 25.4 & 1 & 26.0 & 8 \\
\hline By size ${ }^{2}$ & & & & & & & & \\
\hline Small acquiring small & 4.6 & 24 & 8.1 & 7 & 25.5 & 0 & 27.8 & 4 \\
\hline Medium acquiring small ... & 6.7 & 26 & 9.1 & 0 & 26.0 & 6 & 24.6 & 11 \\
\hline Medium acquiring medium & 7.3 & 28 & 7.8 & -2 & 23.1 & -1 & 24.1 & 10 \\
\hline Large acquiring small ..... & 9.5 & 28 & 13.3 & -7 & 24.2 & -17 & 26.7 & -7 \\
\hline Large acquiring medium & 8.1 & 31 & 11.7 & -3 & 27.9 & 1 & 24.6 & 10 \\
\hline Large acquiring large & 7.2 & 38 & 13.8 & -10 & 28.1 & 10 & 25.0 & 7 \\
\hline
\end{tabular}




\section{8.-Continued}

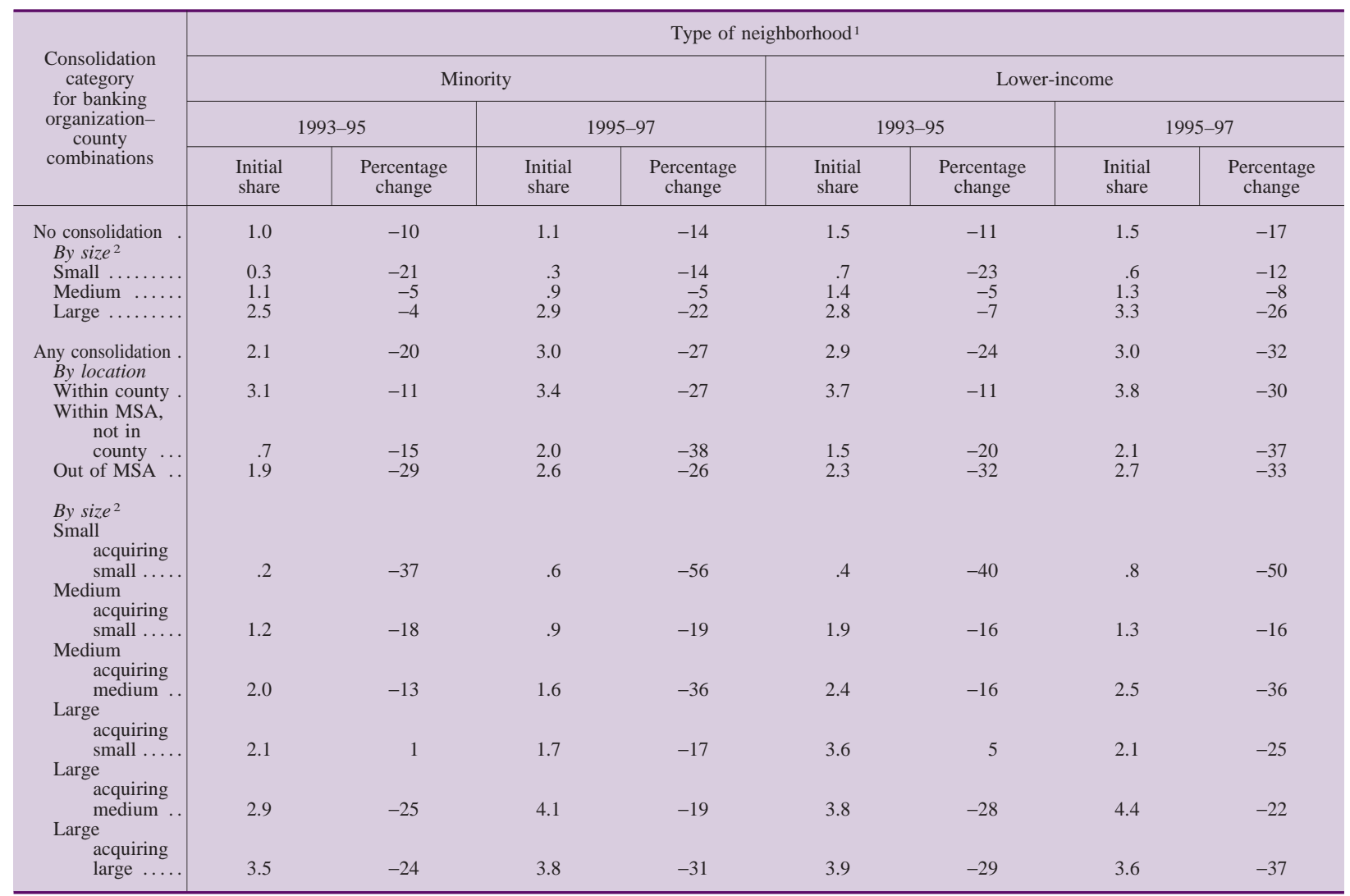

Note. Data are the initial median market share for each category of banking

1. See note 1 to table 3 . organization-county combination and the median change in market share for each

2. See note 1 to table 6 . period.

\section{9.-Continued}

\begin{tabular}{|c|c|c|c|c|c|c|c|c|}
\hline \multirow{4}{*}{$\begin{array}{c}\text { Consolidation } \\
\text { category } \\
\text { for banking } \\
\text { organization- } \\
\text { county } \\
\text { combinations }\end{array}$} & \multicolumn{8}{|c|}{ Type of neighborhood ${ }^{1}$} \\
\hline & \multicolumn{4}{|c|}{ Minority } & \multicolumn{4}{|c|}{ Lower-income } \\
\hline & \multicolumn{2}{|c|}{$1993-95$} & \multicolumn{2}{|c|}{ 1995-97 } & \multicolumn{2}{|c|}{ 1993-95 } & \multicolumn{2}{|c|}{ 1995-97 } \\
\hline & $\begin{array}{c}\text { Initial } \\
\text { share }\end{array}$ & $\begin{array}{l}\text { Percentage } \\
\text { change }\end{array}$ & $\begin{array}{l}\text { Initial } \\
\text { share }\end{array}$ & $\begin{array}{l}\text { Percentage } \\
\text { change }\end{array}$ & $\begin{array}{l}\text { Initial } \\
\text { share }\end{array}$ & $\begin{array}{l}\text { Percentage } \\
\text { change }\end{array}$ & $\begin{array}{c}\text { Initial } \\
\text { share }\end{array}$ & $\begin{array}{c}\text { Percentage } \\
\text { change }\end{array}$ \\
\hline $\begin{array}{c}\text { No consolidation } \\
B y \text { size } e^{2}\end{array}$ & 7.3 & 2 & 6.7 & -5 & 7.1 & 4 & 7.7 & -8 \\
\hline Small. & 2.6 & 0 & 2.0 & -6 & 6.4 & 1 & 6.7 & -8 \\
\hline Medium & 7.9 & 4 & 6.7 & -4 & 6.8 & 6 & 7.0 & -9 \\
\hline Large .. & 12.1 & 2 & 10.7 & -5 & 8.7 & 6 & 9.0 & -7 \\
\hline Any consolidation & 7.9 & 7 & 12.2 & -2 & 7.5 & 11 & 8.5 & -7 \\
\hline By location & & & & & & & & \\
\hline Within county $\ldots \ldots \ldots \ldots$ & 9.2 & 9 & 17.7 & -3 & 7.4 & 12 & 9.5 & -6 \\
\hline Within MSA, not in county & 2.3 & 22 & 8.9 & -9 & 6.3 & 21 & 6.7 & -9 \\
\hline Out of MSA $\ldots \ldots \ldots \ldots$ & 8.1 & 3 & 9.8 & 0 & 7.9 & 8 & 7.5 & -7 \\
\hline By size ${ }^{2}$ & & & & & & & & \\
\hline Small acquiring small & 5.7 & -1 & 9.1 & -21 & 6.8 & -6 & 8.0 & -10 \\
\hline Medium acquiring small & 10.4 & 9 & 13.5 & 0 & 6.9 & 9 & 7.2 & -6 \\
\hline Medium acquiring medium & 8.8 & 3 & 7.3 & 0 & 6.8 & 2 & 8.0 & -2 \\
\hline Large acquiring small ..... & 16.1 & 0 & 16.0 & 1 & 8.7 & -1 & 9.1 & 19 \\
\hline Large acquiring medium .... & 8.8 & 10 & 14.5 & -3 & 8.0 & 18 & 9.1 & -9 \\
\hline Large acquiring large .. & 6.2 & 14 & 13.6 & -3 & 8.3 & 25 & 8.6 & -9 \\
\hline
\end{tabular}

Note. Data are the initial median portfolio share for each category of banking organization-county combination and the median change in share for each period.

1. See note 1 to table 3

2. See note 1 to table 6 . 
A.1. Distribution of MSA counties per banking organization and depository offices and home purchase loans per organization-county combination, 1993, 1995, and 1997

\begin{tabular}{|c|c|c|c|c|c|c|}
\hline \multirow{2}{*}{ Item } & \multicolumn{2}{|c|}{1993} & \multicolumn{2}{|c|}{1995} & \multicolumn{2}{|c|}{1997} \\
\hline & Number & Percent & Number & Percent & Number & Percent \\
\hline \multicolumn{7}{|c|}{$\begin{array}{l}\text { Number of MSA counties with branch offices } \\
\text { per organization }\end{array}$} \\
\hline & 3,923 & 71.4 & 3,423 & 69.4 & 3,124 & 67.2 \\
\hline 2 & 843 & 15.3 & 832 & 16.9 & 836 & 18.0 \\
\hline 3 & 291 & 5.3 & 264 & 5.4 & 268 & 5.8 \\
\hline $4-5$ & 194 & 3.5 & 187 & 3.8 & 197 & 4.2 \\
\hline $6-9$. & 100 & 1.8 & 93 & 1.9 & 96 & 2.1 \\
\hline $10-19$ & 79 & 1.4 & 69 & 1.4 & 54 & 1.2 \\
\hline $20-49 \quad \ldots$ & 55 & 1.0 & 47 & 1.0 & 49 & 1.0 \\
\hline 50 or more & 13 & .2 & 17 & .3 & 22 & .5 \\
\hline Total & 5,498 & 100.0 & 4,932 & 100.0 & 4,646 & 100.0 \\
\hline \multicolumn{7}{|c|}{$\begin{array}{l}\text { Depository offices per organization- } \\
\text { county combination }\end{array}$} \\
\hline & 4,216 & 35.9 & 3,781 & 34.1 & 3,764 & 34.0 \\
\hline 2 & 2,124 & 18.1 & 1,980 & 17.9 & 1,962 & 17.7 \\
\hline 3 & 1,316 & 11.2 & 1,296 & 11.7 & 1,235 & 11.1 \\
\hline $4-5$ & 1,472 & 12.5 & 1,426 & 12.9 & 1,441 & 13.0 \\
\hline $6-9$ & 1,273 & 10.8 & 1,258 & 11.4 & 1,277 & 11.5 \\
\hline 10 or more & 1,338 & 11.4 & 1,339 & 12.1 & 1,394 & 12.6 \\
\hline Total & 11,739 & 100.0 & 11,080 & 100.0 & 11,073 & 100.0 \\
\hline \multicolumn{7}{|c|}{$\begin{array}{l}\text { Home purchase loans per organization- } \\
\text { county combination }\end{array}$} \\
\hline & 1,336 & 11.4 & 1,026 & 9.3 & 1,476 & 13.3 \\
\hline $1-9$. & 2,894 & 24.7 & 2,494 & 22.5 & 2,277 & 20.6 \\
\hline 10-19 & 1,471 & 12.5 & 1,430 & 12.0 & 1,292 & 11.7 \\
\hline $20-49 \quad \ldots \ldots$ & 2,142 & 18.2 & 2,091 & 18.9 & 2,065 & 18.7 \\
\hline 50-99 & 1,531 & 13.0 & 1,581 & 14.3 & 1,507 & 13.6 \\
\hline $100-499$ & 2,064 & 17.6 & 2,144 & 19.4 & 2,102 & 19.0 \\
\hline 500 or more & 301 & 2.6 & 314 & 2.8 & 354 & 3.2 \\
\hline Total & 11,739 & 100.0 & 11,080 & 100.0 & 11,073 & 100.0 \\
\hline
\end{tabular}

The location (county) of banking institution depository offices (banking offices) was extracted from the annual Summary of Deposits filings for commercial banks and Branch Office Survey System filings for savings associations for the years 1993 through 1997. The office list includes all locations qualifying as separate institution deposit-taking offices under federal guidelines as of June 30 of each year. It does not necessarily include all "drive-ins," ATMs, or loan production offices; however, virtually all offices whose presence implies a CRA obligation are reported. Reporting banking institutions include all federally insured commercial banks, savings and loan associations, cooperative banks, and mutual savings banks, as defined by the Federal Reserve Board's National Information Center (NIC) database. The locations used for this study may differ slightly from those used elsewhere because of some limited data cleaning required for the analysis. For example, some offices were added for a few institutions that did not submit a Summary of Deposits or Branch Office Survey System filing, and some addresses were corrected for a limited number of offices for which incorrect county location was reported.

Information on home purchase loan originations used in the analysis was obtained from individual mortgage loan data filed under the 1989 amendments to the Home Mortgage Disclosure Act (HMDA). Each year, nearly all commercial banks, savings and loan associations, credit unions, and other mortgage lending institutions (primarily mortgage banks) with assets of more than \$10 million (raised to \$29 million in 1997) and an office in an MSA are required to report on each mortgage loan purchased and on each loan application related to a one- to four-unit residence acted upon during the calendar year. Lenders must report the loan amount, state, county, and census tract of the property, whether the property would be owner occupied, purpose of the loan, type of loan (conventional, FHA, or VA), application disposition (loan originated, application withdrawn, or application denied), race and gender of the loan applicant, and the applicant income relied on by the lending institution in making the loan decision. ${ }^{27}$ For this

27. See Glenn B. Canner and Dolores S. Smith, "Home Mortgage Disclosure Act: Expanded Data on Residential Lending," Federal Reserve Bulletin, vol. 77 (November 1991), pp. 859-81, for a comprehensive discussion of the HMDA data. It is estimated that 80 percent to 87 percent of all home purchase loans were reported under HMDA for the 1993-97 period. The FFIEC makes the HMDA data available in various formats, including paper summaries, magnetic tape, PC diskette, CD-ROM, and at the FFIEC web site (www.ffiec.gov). An order form for the HMDA data may be obtained by calling the FFIEC at (202) 634-6526 or by downloading the form from the FFIEC web site. 
study, the sample was restricted to loans originated for the purchase of owner-occupied units. The sample includes both conventional loans and loans backed by government guarantees.

Information on the census tract location of the property being purchased was used to determine which loans were originated in lower-income or minority neighborhoods. Loans for properties in census tracts whose 1990 median family income was less than 80 percent of the 1990 median family income of their MSA were classified as loans to lower-income neighborhoods. Similarly, loans for properties in census tracts with more than 20 percent minority residents in 1990 were classified as loans to minority (black, Asian, Hispanic, Native American, and "other race") neighborhoods. The race of the primary applicant was used to determine minority borrower loans, and loans to borrowers whose income was below 80 percent of the current-year median family income of their MSA were classified as loans to lowerincome borrowers.

Under current law, most institutions with offices in MSAs are required to report all their mortgage lending regardless of location but to provide geographic detail only for loans originated in metropolitan areas. Thus, the information needed to determine lending to lower-income and minority neighborhoods was available only for counties in MSAs. Consequently we restricted the dataset to these counties. Further, because the number and boundaries of MSAs changed slightly from 1993 to 1997, the dataset was limited to the 726 counties that were part of MSAs in both 1993 and 1997.28 These counties represent about 20 percent of all counties in the United States but contain 78 percent of the total population and 70 percent of the banking offices.

A further step had to be taken to align the banking office and lending data. Banking institutions report their offices as of June 30 of each year but file HMDA reports on a calender-year basis. The institution's current structure is used for each filing. Thus, for example, if two banking institutions merged on December 15, they would file a consolidated HMDA filing on December 31 showing their combined lending for the whole year. However, their branch office filing, done as of the previous June 30, would show them as separate institutions. To reconcile these differences, the institution's structure as of the end of the year was used to classify bank branches and to

28. To correspond to the taxonomy used by the Bureau of the Census in constructing county-level economic data, information for some counties was combined. Primarily this involved consolidating some independent cities in Virginia with their surrounding counties. determine those counties where in our construct they had a CRA obligation. These numbers may differ from the actual location of offices at the end of the year to the extent that banking institutions may have opened or closed offices in the six-month period between June 30 and December 31.

The final information needed for the study was to determine the appropriate structure to use in classifying banking institutions and to determine which institutions were involved in consolidation during the 1993-95 and 1995-97 study periods. Transactions and structure information recorded in the Federal Reserve Board's NIC database was used for this purpose. For each of the three-year study periods used in the analysis, institutions were initially classified by their membership in banking organizations as of December 31 of the first year of the study period (1993 or 1995). These organizations included bank and thrift holding companies and foreign bank payment groups (commercial banks chartered in the United States that are subsidiaries of a common foreign bank). Both lending and office data were consolidated at the organization level. Thus, for example, if any banking institution member of a bank holding company had an office in a county, the organization was deemed to have a CRA obligation there. Similarly, all home purchase lending in the county, including lending by mortgage bank or finance company subsidiaries of the holding company and by all its member banks and their subsidiaries, was included in determining the organization's total home purchase lending in the county. The size of an organization was computed as the sum of the assets of its member banking institutions. ${ }^{29}$ Banking institutions that were not members of a larger organization were treated as independent organizations.

A similar method was used to reclassify banking institutions by their membership in organizations at the end of each of the three-year study periods. A banking institution that merged into another institution would be reclassified as part of the acquiring institution, for example, and members of a holding company acquired by another holding company would similarly be reclassified as part of the acquiring holding company.

All organizations (or institutions) with different membership at the beginning and end of each study period were deemed to have undergone a "consolida-

29. This amount may differ somewhat from the total assets reported by bank and thrift holding companies for their combined operations. However, consolidated information was not available for foreign bank payment groups; consequently we decided to use a common basis in estimating an organization's size. 
tion" during the period. ${ }^{30}$ This includes both banking institutions and holding companies that acquired or merged with previously independent banking institutions or holding companies. It does not include, however, mergers among subsidiaries of the same holding company, because they were already members of the same organization at the beginning of the period. Nor does it include acquisitions of nonbank affiliates, such as mortgage or finance companies.

For some of the analysis it was necessary to differentiate between the "acquirer" and "acquired" components of a consolidation. These determinations were not always apparent from the record. Consequently, we decided to designate the largest component of an organization (as measured by its asset size at the beginning of the period) as the "acquirer." All other components were treated as "acquired." Thus if four banking institutions merged into a common holding company over the study period, the institution with the most assets in the beginning of the

30. A few institutions were liquidated in each of the study periods. Similarly, a number of new (de novo) institutions were formed. Cases of both types were excluded from the analysis. Moreover, an organization acquiring a de novo bank is not treated as having undergone a merger because the de novo institution did not exist at the beginning of the period. period would be deemed to have acquired the other three.

Consolidations were measured at the county level. A consolidation was deemed to have occurred in the county only if a banking institution (or organization) with an office in the county at the beginning of the period was acquired by another institution (or organization) during the period. If the acquiring organization also had offices in the county at the beginning of the period it was treated as a within-county consolidation; if the acquiring organization had offices within the MSA, but not the county, it was treated as a within-MSA-but-not-county consolidation. Otherwise the merger was treated as an out-of-MSA consolidation. Note that under this definition, an organization was considered to have undergone a consolidation in a county in which only the acquiring component of the organization had offices at the beginning of the period.

Finally, the change in lending for those counties where organizations underwent consolidation was computed by comparing the sum of the lending in a county by all components of the organization in the first year of the study period (1993 or 1995) with the lending reported by the overall organization in the county in the final year (1995 or 1997). Again, only those counties with acquired components were considered in making this calculation. 